\title{
Transcriptional Analysis of Complementary Sense Genes in Spinach curly top virus and Functional Role of $\mathrm{C2}$ in Pathogenesis
}

\author{
Surendranath Baliji, Janet Sunter, and Garry Sunter \\ Department of Biology, The University of Texas at San Antonio, San Antonio, TX 78249, U.S.A.
}

Submitted 10 July 2006. Accepted 11 September 2006.

\begin{abstract}
Spinach curly top virus (SCTV), the fifth characterized Curtovirus species belonging to the family Geminiviridae, is an agriculturally significant plant pathogen representing an emerging disease threat in the southern United States. The SCTV genome comprises a single DNA chromosome of approximately $3.0 \mathrm{~kb}$, with the potential to code for seven proteins larger than $10 \mathrm{kDa}$ but which relies extensively on the host for replication and transcription of its genome. In this study, we have identified viral and complementary sense transcripts in SCTV-infected plants, confirming a bidirectional transcription strategy for SCTV. The most abundant RNA maps to the virion sense (1.1-kb transcript) and is comparable in size and location to that observed in Beet curly top virus (BCTV). Two complementary sense transcripts (1.7 and $0.7 \mathrm{~kb})$ were identified in SCTVinfected plants. The large, $1.7-\mathrm{kb}$ transcript is comparable in size and position to that identified in BCTV and several begomoviruses and most likely encodes the $\mathrm{C} 1$ protein. Both complementary sense RNAs could potentially direct expression of $\mathrm{C} 2$ and $\mathrm{C} 3$ from polycistronic mRNAs. A mutation in the $C 2$ gene of SCTV results in expression of a truncated protein of $\mathbf{3 8}$ amino acids that is capable of interacting with two cellular kinases, AKIN11 and ADK2, and the resulting mutant virus remains highly infectious. $A$ second mutant virus can only express the first three amino acids of the $\mathrm{C} 2$ protein and is unable to interact with the same kinases. However, this mutant virus still remains infectious, although a reduction in infectivity and symptom severity was seen in both Arabidopsis and spinach. A possible relationship between the interaction of $\mathrm{C} 2$ with AKIN11 and $\mathrm{ADK} 2$ and disease severity is presented.
\end{abstract}

Additional keyword: Geminiviruses.

Plant viruses of the family Geminiviridae are classified into four genera, Mastrevirus, Curtovirus, Topocuvirus, and Begomovirus, based on genome organization, type of insect vector, and host range (Rybicki et al. 2000). The genus Curtovirus consists of five virus species that are leafhopper-transmitted, infect dicotyledonous hosts, and possess a monopartite circular single-strand (ss)DNA genome of approximately $3.0 \mathrm{~kb}$. Spin-

Corresponding author: G. Sunter; E-mail: garry.sunter@utsa.edu; Telephone: +1.210.458.5479; Fax: +1.210.458.5561.

* The $\boldsymbol{e}$-Xtra logo stands for "electronic extra" and indicates that Figures 7 and 8 appear in color on-line. ach curly top virus (SCTV) is only the fifth recognized Curtovirus species and causes infectious disease in economically important plants such as spinach, sugar beets, beans, pumpkin, and carrots (Baliji et al. 2004). Curly top viruses are understudied and, considering the agricultural importance of SCTV, further analysis of viral pathogenesis is needed. Geminiviruses rely extensively on the host for transcription of their genomes, as few viral proteins are encoded, which makes them useful models for the study of transcription in plants. Viral replication takes place in the nuclei of infected plant cells through doublestranded (ds)DNA intermediates (Hanley-Bowdoin et al. 1999; Preiss and Jeske 2003; Stenger et al. 1991) that also serve as template for viral transcription utilizing host RNA polymerase II (Bisaro 1996; Hanley-Bowdoin et al. 1999).

The dsDNA replicative intermediate of SCTV has the potential to code for seven proteins larger than $10 \mathrm{kDa}$ (Fig. 1), with an arrangement typical for curtoviruses (Stanley et al. 1986; Stenger 1994). Three overlapping genes, V1, V2, and V3 (also known as R1, R2, and R3), are encoded in the virion sense strand and four overlapping genes, C1, C2, C3, and C4 (also known as L1, L2, L3, and L4), are encoded in the complementary sense strand (Baliji et al. 2004), which are of interest here. Currently no information is available on how complementary sense genes in general and, more specifically, $\mathrm{C} 2$ are expressed in curtoviruses. Transcripts capable of expressing the begomovirus homolog of C2 (AL2) have been identified in several begomoviruses, but our knowledge regarding RNAs that can express C2 or L2 in curtoviruses is limited. In Beet curly top virus (BCTV)-infected plants, three complementary sense transcripts have been identified, which suggests a transcription strategy similar to Tomato golden mosaic virus (TGMV A; Sunter and Bisaro 1989; Sunter et al. 1989), but high-resolution mapping of these transcripts has not been carried out (Frischmuth et al. 1993). However, the bipartite begomoviruses Abutilon mosaic virus (Frischmuth et al. 1991), African cassava mosaic virus (Townsend et al. 1985), and Mungbean yellow mosaic virus (MYMV A; Shivaprasad et al. 2005), and a monopartite begomovirus Tomato leaf curl virus (Mullineaux et al. 1993) apparently possess only two complementary sense transcripts in infected plants. The role of multiple complementary sense transcripts in expression of $\mathrm{C} 1, \mathrm{C} 2$, and $\mathrm{C} 3$ in curtoviruses is currently unknown and, considering the importance of complementary sense genes in replication $(\mathrm{C} 1$ and $\mathrm{C} 3)$ and pathogenicity $(\mathrm{C} 2)$, this represents a gap in our understanding of transcriptional regulation in curtoviruses.

The L2 gene product of BCTV plays an important role in pathogenesis but shares only limited amino-acid sequence ho- 
mology with the AL2 protein of bipartite begomoviruses (Hormuzdi and Bisaro 1995; Stanley et al. 1992). SCTV C2 is most closely related to Beet mild curly top virus L2 (formerly known as the Worland strain of BCTV) and also shares limited sequence similarity (17\%) with begomovirus AL2 and AC2 proteins (Baliji et al. 2004). Although C2 and AL2 are positional homologs, the SCTV C2 protein lacks an obvious transcriptional activation domain and is unable to complement a mutation in the TGMV AL2 gene (S. Baliji and G. Sunter, unpublished observation). This is consistent with previous data demonstrating that BCTV L2 does not activate transcription (Sunter et al. 1994), unlike the AL2 counterpart in begomoviruses (Sunter and Bisaro 1991, 1992, 1997). Despite limited homology, AL2 and L2 proteins are capable of interacting with an Arabidopsis serine/ threonine protein kinase (AKIN11), and plants transgenic for either AL2 or L2 exhibit an enhanced susceptibility phenotype (Hao et al. 2003; Sunter et al. 2001). A second interaction of AL2 and L2 with adenosine kinase (ADK2), a key component of the 5'-AMP salvage pathway (Wang et al. 2003), may play a role in the ability of these proteins to suppress gene silencing (Wang et al. 2005), which acts to limit virus infection (Baulcombe 1999; Carrington et al. 2001; van Wezel et al. 2002). These results suggest that geminivirus C2, L2, or AL2 gene products employ multiple strategies for countering antiviral defenses.

Although L2 in curtoviruses and AL2 in begomoviruses share the ability to suppress a host defense response (Sunter et al. 2001), viruses with mutations in the L2 gene of BCTV remain highly infectious in both Nicotiana benthamiana and sugar beet (Hormuzdi and Bisaro 1995; Stanley et al. 1992). Under some circumstances, $N$. benthamiana plants inoculated with BCTV $l 2$ mutant viruses exhibit an "enhanced recovery" phenotype in which plants appear to recover from infection (Hormuzdi and Bisaro, 1995). However, this phenotype is not always observed and appears to be dependent on both the host and the growth conditions (Stanley et al. 1992), and the reason for this has yet to be resolved.

Here, we present results of transcriptional analysis of SCTVencoded RNAs and identify complementary sense transcripts capable of expressing SCTV C2. We also extend our investigation on the functional role of $\mathrm{C} 2$ by demonstrating that SCTV containing mutations in the $\mathrm{C} 2$ open reading frame (ORF) cause a unique disease phenotype distinct from that previously reported (Hormuzdi and Bisaro 1995; Stanley et al. 1992). We propose that interaction of SCTV C2 with AKIN11 and ADK2 is important for virulent disease progression in Arabidopsis and also in spinach, the host in which the virus was first identified.

\section{RESULTS}

\section{Identification of virus-specific RNAs in SCTV-infected plants.}

RNA gel blots of total cellular poly (A) ${ }^{+}$RNA from SCTVinfected spinach, Arabidopsis, and N. benthamiana tissue are shown in Figure 2. Hybridization to a full-length SCTV (-) sense probe revealed a single predominant RNA of $1.1 \mathrm{~kb}$ in samples isolated from the three plant species tested (Fig. 2A, lanes 2, 4, and 6). This RNA is of the viral sense, is transcribed from the complementary sense DNA template and was not detected in comparable extracts from healthy, noninoculated tissue (Fig. 2A, lanes 1, 3, and 5). In similar experiments, two virusspecific RNAs of 1.7 and $0.7 \mathrm{~kb}$ were detected in SCTV-infected spinach, Arabidopsis, and N. benthamiana tissue using a fulllength SCTV (+) sense probe (Fig. 2B, lanes 2, 4, and 6). These two RNAs are of the complementary sense and are thus transcribed from the viral sense DNA template. However, these
RNAs were not detected in comparable extracts from healthy, noninoculated tissues (Fig. 2B, lanes 1, 3, and 5). RNA gelblot analysis using a DNA probe specific for the N-terminal region of the $\mathrm{C} 1 \mathrm{ORF}$ only detected the larger $1.7-\mathrm{kb}$ transcript (data not shown), consistent with the C1 ORF being contained within this larger transcript.

\section{High-resolution mapping} of the SCTV virion sense transcript.

The location of the $5^{\prime}$ end for the virion sense transcript was determined by both high-resolution $\mathrm{S}_{1}$ nuclease protection and primer extension assays (Sunter and Bisaro 1989). Poly (A) ${ }^{+}$ RNA isolated from SCTV-infected $N$. benthamiana leaf tissue protected three DNA fragments of 400, 360, and $240 \mathrm{nt}$ when a ${ }^{32} \mathrm{P}$-labeled dsDNA probe spanning the intergenic region of SCTV (coordinates 657 to 2,886; Fig. 1) was used in $S_{1}$ nuclease protection assays (Fig. 3A, lane 3 ). These protected products represent virion sense RNAs with $5^{\prime}$ termini mapping to nucleotides 257, 297, and 417, respectively (Fig. 3C). Protected fragments were not detected in reactions containing RNA isolated from healthy $N$. benthamiana leaf tissue (Fig. 3A, lane 2).

Location of the $5^{\prime}$ end of the virion sense transcript was also determined by primer extension, using labeled synthetic oligonucleotides complementary to a region downstream of the AUG translation start codons for V1 and V2 (Fig. 1). Primer extension reactions, using primer V1Pxt with RNA isolated from SCTV-infected $N$. benthamiana leaf tissue, identified two cDNA products of 405 and 365 nt (Fig. 3B, lane 2). These extension

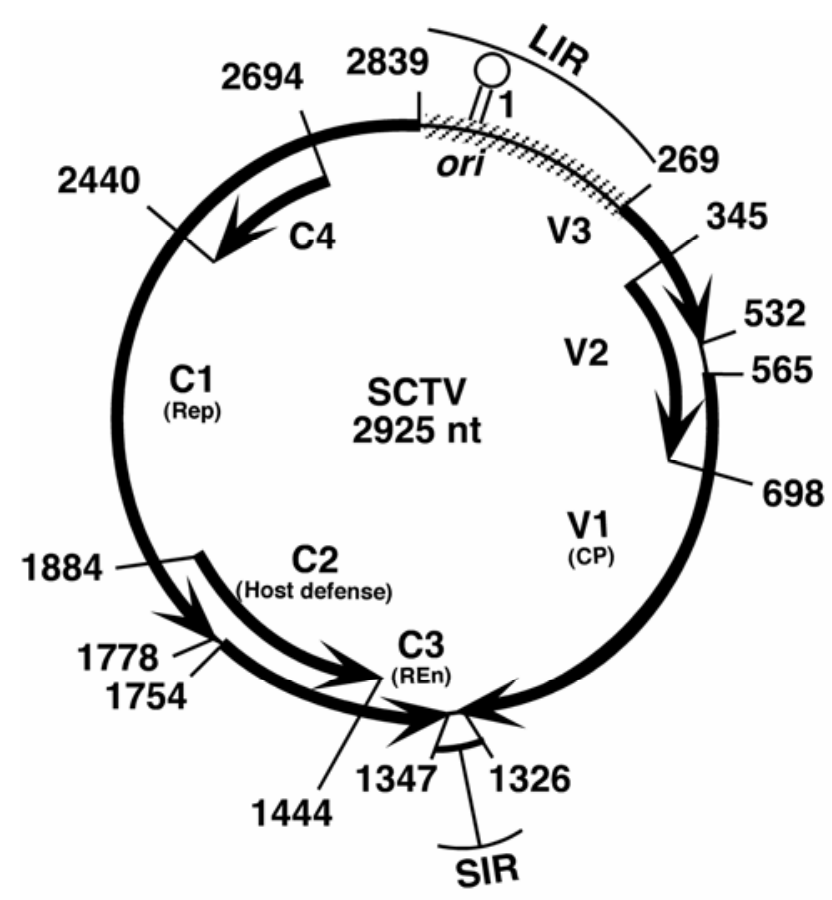

Fig. 1. Genome organization of Spinach curly top virus (SCTV). The circular map illustrates the wild-type SCTV genome component, with nucleotide coordinates given according to the sequence determined by Baliji and associates (2004). Solid arrows indicate the location and polarity of open reading frames encoded by the virion (V1, V2, and V3) or complementary $(\mathrm{C} 1, \mathrm{C} 2, \mathrm{C} 3$, and $\mathrm{C} 4)$ sense DNA strand. The predicted gene function is indicated in parentheses, based on sequence and positional homology to Beet curly top virus genes as described previously (Baliji et al. 2004). The large intergenic region (LIR) located between nucleotides 2,840 to 268 is indicated by hatched lines and contains the origin of plus strand DNA replication (ori). The small intergenic region (SIR), located between the converging $V 1$ and $C 3$ genes (nucleotides 1,327 to 1,346 ), is indicated with a solid line. 
products represent RNAs with 5' ends mapping to nucleotides 252 and 292, respectively (Fig. 3C). Primer extension reactions using V23Pxt identified four extension products of 192, 180, 160, and $152 \mathrm{nt}$ (Fig. 3B, lane 4). Products of 192 and $152 \mathrm{nt}$ represent RNAs with $5^{\prime}$ ends mapping to nucleotides 252 and 292, matching extension products identified with primer V1Pxt and in close agreement with 5' ends at nucleotides 257 and 297 mapped by $S_{1}$ protection assays. Two additional products represent RNAs with 5' ends at nucleotides 264 and 284 (Fig. 3C). Extension products were absent in reactions using RNA isolated from healthy $N$. benthamiana leaf tissue (Fig. 3B, lanes 1 and 3).
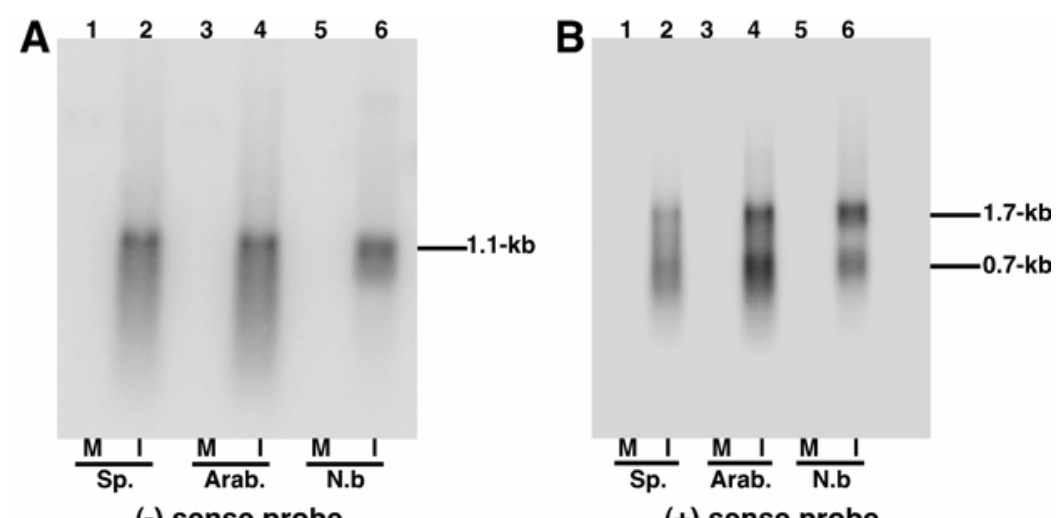

$(-)$ sense probe

(+) sense probe

Fig. 2. Detection of virus-specific RNAs in Spinach curly top virus (SCTV)-infected plants. The panels illustrate RNA gel blots analyzed by phosphorimager. Aliquots of polyadenylated RNA ( 2 to $5 \mu \mathrm{g})$ were fractionated on formaldehyde agarose gels $(1.2 \%)$ and were transferred to nitrocellulose. Immobilized RNA was hybridized to SCTV probes specific for A, viral (-) sense and $\mathbf{B}$, complementary (+) sense RNAs. Lanes 2, 4, and 6 in each panel contain poly (A) $)^{+}$RNA isolated from SCTV-infected (I) spinach (Sp.), Arabidopsis (Arab.), and Nicotiana benthamiana (N.b) tissue, respectively. Lanes 1, 3, and 5 in each panel contain poly $(\mathrm{A})^{+}$RNA isolated from mock-inoculated (M) spinach, Arabidopsis, and N. benthamiana tissue, respectively. Sizes are given in kilobases (kb).
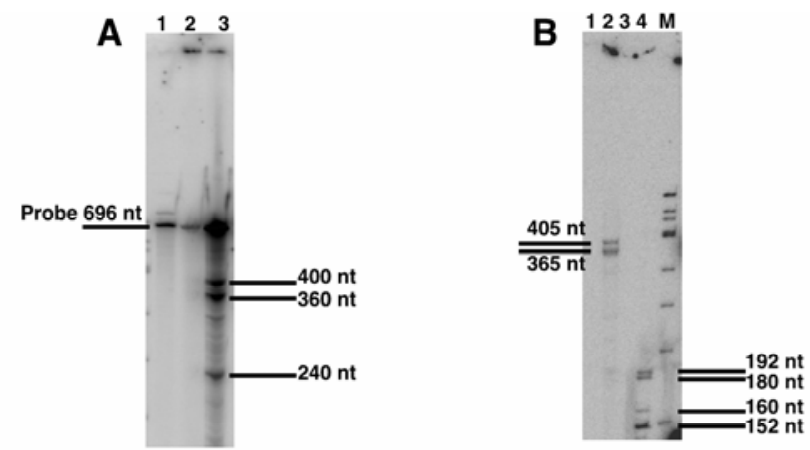

C 18

GAC TGT GGT CCC CAC AGg AAA CTT GCT CAG CAA GTT TCG AAT AAT GTC GGT TFA TRP ACG CTG ACA CCA GGG GTG TCC TTT GAA CGA GTC GTT CAA AGC TTA TTA CAG CCA AAT ATA TGC

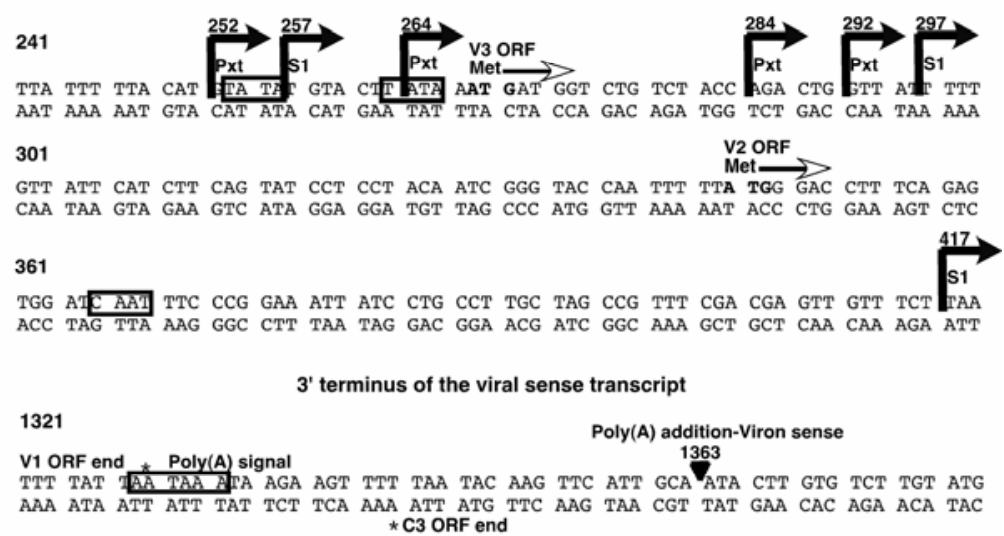

Fig. 3. High-resolution mapping of the Spinach curly top virus (SCTV) virion sense transcription unit. Panels illustrate phosphorimager analysis of A, $\mathrm{S}_{1}$ protection and $\mathbf{B}$, primer extension products. A, Poly $(\mathrm{A})^{+}$RNA $(100 \mathrm{ng}$ ) isolated from healthy (lane 2$)$ or SCTV-infected (lane 3 ) leaf tissue was hybridized to a ${ }^{32} \mathrm{P}-$ labeled double-stranded DNA probe (lane 1), labeled at nucleotide 657 within the V1 open reading frame (ORF). B, Poly (A) $)^{+} \mathrm{RNA}(1 \mu \mathrm{g})$ isolated from healthy (lanes 1 and 3) or SCTV-infected (lanes 2 and 4) leaf tissue was annealed to ${ }^{32}$ P-labeled primers V1Pxt (lanes 1 and 2) or V23Pxt (lanes 3 and 4). The sizes of products detected are given in nucleotides (nt) as determined by comparison to labeled DNA fragments from $\Phi$ X174 digested with HinfI (M). C, Part of the SCTV genome sequence surrounding the viral sense transcript termini is given. The nucleotide sequence in the top strand is of viral sense polarity. Solid bent arrows indicate major transcription start sites, identified by various techniques, along with direction of transcription. The methionine (Met) amino acid designating the start of the V2 and V3 ORFs is shown in bold letters, and open arrows indicate direction of translation. The translation stop codons for the V1 and C3 ORFs are designated with an asterisk. Potential polyadenylation, TATA box, and CAAT box sequences are shown in boxes. The 3' end for virion sense transcript is indicated by a solid triangle. 
Table 1. Sequence of oligonucleotides used for mapping Spinach curly top virus (SCTV)-specific transcript termini, cloning of DNA constructs for yeast two-hybrid analysis, and mutagenesis

\begin{tabular}{|c|c|c|}
\hline Primer name & Oligonucleotide sequence $^{a}$ & $\begin{array}{l}\text { Nucleotide } \\
\text { coordinates }^{\text {b }}\end{array}$ \\
\hline V1Pxt & $5^{\prime}$-catcgtcttcctcttcttcg-3' & 657 to 638 \\
\hline V23Pxt & $5^{\prime}$-ctagtatacaccacctgttg- $3^{\prime}$ & 444 to 425 \\
\hline C1Pxt & $5^{\prime}$-gagattgctagaagctgttc- $3^{\prime}$ & 2,745 to 2,764 \\
\hline $\mathrm{C} 2 \mathrm{Pxt}$ & $5^{\prime}$-ccacctttaatgacacgtgg- $3^{\prime}$ & 1,956 to 1,975 \\
\hline C3Pxt & $5^{\prime}$-gactgctctggtcgcctgtt- $3^{\prime}$ & 1,689 to 1,708 \\
\hline R4 & $5^{\prime}$-ggaattggttctaccattagt- $3^{\prime}$ & 745 to 764 \\
\hline $\begin{array}{l}\text { Oligo }(\mathrm{dT}) \\
\text { adapter }\end{array}$ & $5^{\prime}$-gcgagatcttttttttttttt- $3^{\prime}$ & N/A \\
\hline C3 ORF $5^{\prime}$ & $5^{\prime}$ - cgcagatctatgaatgtcatcagggattttcgc- $3^{\prime}$ & 1,754 to 1,724 \\
\hline $\begin{array}{l}5^{\prime} \text { RNA } \\
\text { adapter }\end{array}$ & $\begin{array}{l}5^{\prime} \text {-gcugauggcgaugaaugaacacugcguuugcu } \\
\text { ggcuuugaugaaa- } 3^{\prime}\end{array}$ & N/A \\
\hline $\begin{array}{l}5^{\prime} \mathrm{RACE}^{\mathrm{c}} \\
\text { outer }\end{array}$ & $5^{\prime}$-gctgatggcgatgaatgaacactg- $3^{\prime}$ & N/A \\
\hline$B g l I I$ & $5^{\prime}$-gcgagatctgcacgcggaggtcaacagacg-3' & 2,491 to 2,464 \\
\hline C 2 ORF $5^{\prime}$ & $5^{\prime}$-gcgatatccatatgaagcgcttaagtcctggacgc- $3^{\prime}$ & 1,884 to 1,860 \\
\hline C2 ORF $3^{\prime}$ & $5^{\prime}$-gcgctgcagctcgagttaatagagatcgtttccetc- $3^{\prime}$ & 1,441 to 1,462 \\
\hline AKIN11 5' & $5^{\prime}$-gcgetcgagccatggatcattcatc- $3^{\prime}$ & N/A \\
\hline AKIN11 3' & $5^{\prime}$-gcgggatcetcagatcacacggaagc- $3^{\prime}$ & N/A \\
\hline $\mathrm{C} 2-39 \mathrm{a}$ & $5^{\prime}$-ctaccatgtaagtTcTaGAttacaattcatc- $3^{\prime}$ & 1,785 to 1,755 \\
\hline $\mathrm{C} 2-39 \mathrm{~b}$ & 5'-gatgaattgtaa TCtTgTacttacatggtag-3' & 1,755 to 1,785 \\
\hline $\mathrm{C} 2-4 \mathrm{~m}$ & $5^{\prime}$-gcggaattctgtagcgtccaggacttTagcgcttc- $3^{\prime}$ & 1,851 to 1,882 \\
\hline ClaI & $5^{\prime}$-ctgctgcagcatcattagc- $3^{\prime}$ & 2,446 to 2,464 \\
\hline M13F & $5^{\prime}$-cccagtcacgacgttgtaaaacg- $3^{\prime}$ & N/A \\
\hline M13R & $5^{\prime}$-agcggataacaatttcacacagg- $3^{\prime}$ & N/A \\
\hline
\end{tabular}

${ }^{a}$ Restriction endonuclease sites are indicated in bold, and mutated nucleotides are shown in upper case bold letters. SCTV nucleotide coordinates are according to Baliji and associates (2004).

${ }^{\mathrm{b}} \mathrm{N} / \mathrm{A}=$ not applicable.

${ }^{\mathrm{c}} \mathrm{RACE}=$ rapid amplification of cDNA ends.
The $3^{\prime}$ end of the SCTV virion sense transcript was mapped by sequence analysis of several clones derived from polymerase chain reaction-rapid amplification of cDNA ends (PCR-RACE), using R4 with an oligo (dT) adapter primer (Table 1). One predominant $3^{\prime}$ terminus (nt 1,363) located downstream of the virion sense transcription unit was detected (Fig. 3C).

\section{High-resolution mapping \\ of SCTV complementary sense transcripts.}

The $5^{\prime}$ termini of the 1.7- and $0.7-\mathrm{kb}$ complementary sense transcripts were also determined by primer extension and $S_{1}$ protection assays. Extension reactions using primer C1Pxt (Table 1) with RNA isolated from SCTV-infected $N$. benthamiana leaf tissue identified four extension products of 52, 55, 60, and $121 \mathrm{nt}$ (Fig. 4A, lane 2). These products correspond to RNAs with $5^{\prime}$ ends at nucleotides 2,797, 2,800, 2,805, and 2,866 (Fig. 4C). A single 5' end at nucleotide 2,866 maps $27 \mathrm{nt}$ upstream of the $\mathrm{C} 1 \mathrm{ORF}$, and the remaining three are located within the $\mathrm{C} 1 \mathrm{ORF}$. Using $\mathrm{S}_{1}$ nuclease protection assays with a ${ }^{32} \mathrm{P}$-labeled dsDNA probe spanning the intergenic region (coordinates 2,745 to 2,886 ; Fig. 1 ), a product of approximately 135 nt was protected by RNA isolated from SCTV-infected N. benthamiana leaf tissue (Fig. 4B, lane 3 ). The size of this product corresponds to RNA with a $5^{\prime}$ terminus at nucleotide 2,880, 40 nt upstream of the $\mathrm{C} 1 \mathrm{ORF}$, which closely corresponds to the $5^{\prime}$ end at nucleotide 2,866 identified by primer extension (Fig. 4C).

Primer extension reactions using primer C3Pxt (Table 1) with RNA isolated from SCTV-infected $N$. benthamiana leaf tissue identified one predominant product of $140 \mathrm{nt}$ and one minor product of $151 \mathrm{nt}$ (Fig. 5A, lane 2). These products correspond to RNAs with $5^{\prime}$ termini at nucleotides 1,829 and
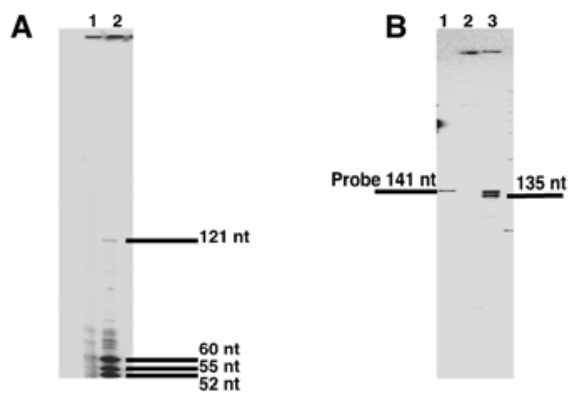

C 2701

GTA ACT CCC TGC TTA TTC TAA TAT ATT TTT TAT TTG ACG GAG TGG AGA TTG CTA GAA GCT CAT TGA GGG ACG AAT AAG ATT ATA TAA AAA ATA AAC TGC CTC ACC TCT AAC GAT CTT CGA 2761

GTT CTA AAG CTT CTT CTT TAG AAA TGG AAC ATT GAG GAT ATG TTA AAA AAT AAT TCT TTC CAA GAT TTC GAA GAA GAA ATC TTT ACC TTG TAA CTC GTA ATG TTA AAA AAT ATT TTA TTA AGA AAC $2821 \quad$ Rep (C1) binding site 2821 Rep (C1) binding
CTT TCC TAT AAA AAG GCA TTT TGT ATT GGG CTC TCT CCA AAA CTT GTT TCA ATT GGG TGC GAA AGG ATA TTT TTC CGT AAA ACA TAA CCC GAG AGA GGT TTT GAA GA AGT TAA CCC AGG

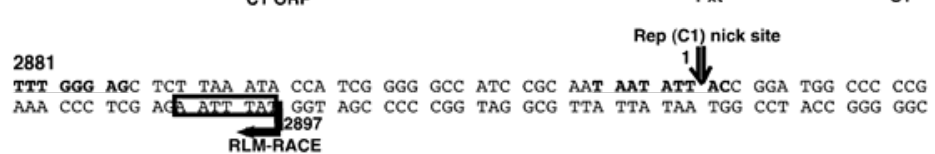

Fig. 4. High-resolution mapping of the 1.7-kb complementary sense transcript. Panels illustrate phosphorimager analysis of $\mathbf{A}$, primer extension and $\mathbf{B}$, $\mathrm{S}_{1}$ protection products. A, Poly (A) ${ }^{+}$RNA $(2.5 \mu \mathrm{g}$ ) isolated from healthy (lane 1) or Spinach curly top virus (SCTV)-infected (lane 2) leaf tissue was annealed to ${ }^{32} \mathrm{P}$-labeled primer C1Pxt (lanes 1 and 2). B, Poly $(\mathrm{A})^{+} \mathrm{RNA}(1 \mu \mathrm{g})$ isolated from healthy (lane 2) or SCTV-infected (lane 3) leaf tissue was hybridized to a ${ }^{32} \mathrm{P}$-labeled double-stranded DNA probe (lane 1), labeled at nucleotide 2,745 within the C1 open reading frame (ORF). Sizes of products detected are given in nucleotides (nt), as determined by comparison to labeled DNA fragments from ФX174 digested with HinfI. C, Part of the SCTV genome sequence surrounding the $\mathrm{C} 15^{\prime}$ terminus is shown. The nucleotide sequence in the bottom strand is of complementary sense polarity. Major transcription start sites and direction of transcription, are indicated by solid bent arrows. The methionine (Met) amino acid designating the start codon for the C1 ORF is shown in bold letters and the open arrow indicates the direction of translation. Potential TATA box sequences are shown in boxes. The origin of plus-strand DNA replication (TAATATTAC), the nick site for $\mathrm{C} 1$ protein, and the $\mathrm{C} 1$ binding site (Baliji et al. 2004) are indicated in bold and underlined. 
1,840 respectively, both of which are internal to the C2 ORF but upstream of ORF C3 (Fig. 5C). Using $\mathrm{S}_{1}$ nuclease protection assays with a ${ }^{32} \mathrm{P}$-labeled dsDNA probe (coordinates 1,689 to 2,486; Fig. 1), RNA isolated from SCTV-infected $N$. benthamiana leaf tissue protected one predominant product of approximately $330 \mathrm{nt}$ (Fig. 5B, lane 2). This protected product corresponds to RNA with a 5' end at nt 2,019 (Fig. 5C). However, this does not correspond to $5^{\prime}$ termini identified by primer extension (Fig. 5A and $\mathrm{C}$ ), which could indicate variability in the $5^{\prime}$ termini of the smaller $0.7-\mathrm{kb}$ transcript. This was substantiated by primer extension reactions using a second labeled primer, C2Pxt (Table 1), with RNA isolated from SCTV-infected $N$. benthamiana leaf tissue, which identified several extension products (not shown). In all cases, extension products were absent in reactions using RNA isolated from healthy $N$. benthamiana leaf tissue.

The $3^{\prime}$ ends of SCTV complementary sense mRNAs were mapped by sequence analysis of several clones derived from PCR-RACE using primer C3 ORF $5^{\prime}$ with an oligo (dT) adapter primer (Table 1). Sequence analysis revealed the presence of three predominant $3^{\prime}$ ends at nucleotides $1,300,1,341$, and 1,348, two of which mapped downstream of the C3 ORF and one mapped within the C3 ORF (Fig. 5C).

\section{Mapping of SCTV complementary sense transcript termini by PCR.}

As the $5^{\prime}$ ends of complementary sense SCTV RNAs displayed great variability, we used RNA ligase-mediated (RLM)RACE and circularization reverse transcriptase-mediated (cRT)-PCR (Shivaprasad et al. 2005) to further map the $5^{\prime}$ and $3^{\prime}$ termini. Sequencing of clones generated by RLM-RACE, using the primer pair C1Pxt and 5' RACE outer primer (Table 1 ), indicated ligation of the RNA adapter primer to RNA with a $5^{\prime}$ end at nucleotide 2,897, which lies upstream of C1 (Fig. 4C). This corresponds closely to a $5^{\prime}$ end mapped to nucleotides 2,866 and 2,880 by primer extension and $S_{1}$ nuclease protection, respectively (Fig. 4C), and most likely represents the 5 ' end for the larger 1.7-kb SCTV transcript. In contrast, sequencing of clones generated by cRT-PCR using the primer pair C2Pxt and C3 ORF 5' end (Table 1), indicated circularization of two different $5^{\prime}$ ends to the $3^{\prime}$ end of SCTV complementary sense transcripts and, most likely, represent $5^{\prime}$ ends
A

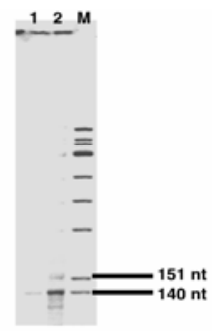

B

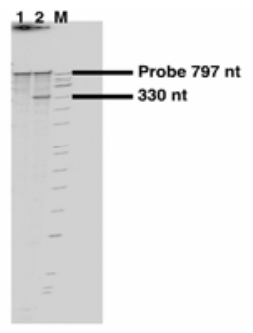

C ${ }^{1741}$

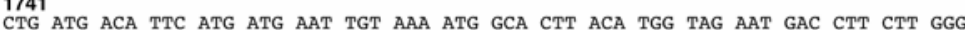
GAC TAC TGT AAG TAC TAC TTA ACA TTT TAC CGT GAA TGT ACC ATC TTA CTG GAA GAA CCC C3 ORF c1 ORF end

1801 GCG TTT CTG Aag CTT TAT CAA AGA GAG GAC CCC AGA TTT TTG CGA AGG TTG AAT TCT GTA CGC AAA GAC TTC GAA ATA GTT TCT CTC CTG GGG TCT AAA AAC GCT TCC AAC TTA AGA CAT $\sum_{\text {CRT-PCR }}^{1807}$ 1861

TCC AGG ACT TAA GCG CTT CAT TCT CTT GTT TAT CTA AGA AGT CCT GGT AGC TAC TCC CGC AGG TCC TGA ATT CGC GAA GTA AGA GAA CAA ATA GAT TCT TCA GGA CCA TCG ATG AGG 1921 C2 ORF

CTT CGC CTG GGT TGC ATA ATA TAA TAC TAG GAA TAC CAC CTT TAA TGA CAC GTG GTT TTC GAA GCG GAC CCA ACG TAT TAT ATT ATG ATC CTT ATG GTG GAA ATT ACT GTG CAC CAA AAG 1981

CAT ACT TTA AAT TTG TCT GCC ACT CTC TTT GAG CGC CTA TTA GAT GCT TCC AGT GCT TCA GTA TGA AAT TTA AAC AGA CGG TGA GAG AAA CTC GCG GAT AAT CTA CGA AGG TCA CGA AGT 2019 CRT-PCR and S1

2041 TCT AGT AAT TGG GAT CCA CAT CAT CAA TGA CGT TAT ATA GTA CGT CAT CAC TAT ATG AGA AAT TCA TAA TA CTA GGT GTA GTA GTT ACT GCA ATA TAT CAT GCA GTA GTG ATA TAC 2045 CRT-PCR

261

3' termini of viral and complementary sense transcripts

1261

AAT GAT AAT ACA GAC AAT ACA AAC ATG TAT GCT ACT TTG TTT GGA AAT TGT AGA TGC TAT TTA CTA TTA TGT CTG TTA TGT TTG TAC ATA CGA TGA AAC AAA CCT TTA ACA TCT ACG ATA

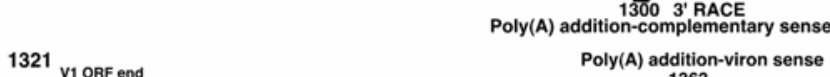

1321 V1 ORF end Poly(A) addition-viron sens

TTT TAT TAA TAA ATA AGA AGT TTT TAA TAC AAG TTC ATT GCA ATA CTT GTG TCT TGT ATG TTT TAT TAA TAA ATA AGA AGT TTT TAA TAC AAG TTC ATT GCA ATA CTT GTG TCT TGT ATG
MA ATA Al T ATT TAT TCT TCA AAA ATT ATG TTC AAG TAA CGT TAT GAA CAC AGA ACA TAC $\begin{array}{lll}\text { Poly(A) signal } & 1341_{\text {C3 ORF end }}^{1348} \\ \text { 3' RACE }\end{array}$

Fig. 5. High-resolution mapping of the $0.7-\mathrm{kb}$ complementary sense transcript. Panels illustrate phosphorimager analysis of $\mathbf{A}$, primer extension and $\mathbf{B}$, $\mathrm{S}_{1}$ protection products. A, Poly (A) ${ }^{+}$RNA $(2.5 \mu \mathrm{g}$ ) isolated from healthy (lane 1) or Spinach curly top virus (SCTV)-infected (lane 2) leaf tissue was annealed to ${ }^{32} \mathrm{P}$-labeled primer C3Pxt (lanes 1 and 2). The sizes of products detected are given in nucleotides (nt), as determined by comparison to labeled DNA fragments from $\Phi$ X174 digested with $\operatorname{HinfI}(\mathrm{M})$. B, Poly (A) ${ }^{+}$RNA $(1 \mu \mathrm{g})$ isolated from healthy (lane 1) or SCTV-infected (lane 2) leaf tissue was hybridized to a ${ }^{32} \mathrm{P}$-labeled double-stranded DNA probe labeled at nucleotide 1,689 within the C3 open reading frame (ORF). C, The SCTV genome sequence surrounding the $\mathrm{C} 2$ and $\mathrm{C} 3 \mathrm{ORFs}$ and the $3^{\prime}$ end of V1 is given. The nucleotide sequence in the bottom strand is of complementary sense polarity. Solid bent arrows indicate major transcription start sites, identified by various techniques, along with the direction of transcription. Open bent arrows indicate minor transcription start sites between $\mathrm{C} 2$ and C3 start codons. The methionine (Met) amino acid designating the beginning of the C2 and C3 ORFs is shown in bold letters, and open arrows indicate the direction of translation (Baliji et al. 2004). The translation stop codon for the C1, C3, and V1 ORFs is designated with an asterisk. Potential polyadenylation, TATA box, and CAAT box sequences are shown in boxes. The $3^{\prime}$ ends for complementary sense transcripts and viral sense transcript are indicated by solid triangles. 
for the smaller 0.7-kb transcript (Fig. 5C). Both mapped upstream of the $\mathrm{C} 2$ and $\mathrm{C} 3$ coding region, with one end located at nucleotide 2,019, consistent with $\mathrm{S}_{1}$ nuclease protection, (Fig. 5B), and the second at nucleotide 2,045 (Fig. 5C). In addition, one minor product associated with a poly (A) tail was identified by cRT-PCR, which mapped to nucleotide 1,807 , between the C2 and C3 ATG codons (Fig. 5C), which is again in close agreement with $5^{\prime}$ ends mapped by primer extension (Fig. 5A and C). Results have identified two complementary sense transcripts capable of expressing the SCTV C2 protein, which is homologous to TGMV AL2 and BCTV L2, which are involved in suppression of host defense responses. Our data suggests that another curtovirus, SCTV, also encodes a protein that is predicted to function in pathogenicity.

\section{Mutational analysis of SCTV C2 \\ in $N$. benthamiana protoplasts.}

We analyzed the function of SCTV C2 in viral replication by introducing single and double mutations into the C2 ORF. The first mutation introduced an $\mathrm{XbaI}$ restriction site within the $\mathrm{C} 2$ ORF (coordinates 1,773 to 1,768 ), which creates a termination codon after amino acid 38, resulting in virus capable of producing a truncated $\mathrm{C} 2$ protein of 38 amino acids (C2-39). A second mutation introduced at nucleotide 1,874 within $\mathrm{C} 2-39$ creates a double mutant (C2-4), resulting in virus that can theoretically produce only the first three amino acids of $\mathrm{C} 2$ and is essentially a null mutant. The nucleotide change in $c 2-4$ mutant virus also introduces a silent mutation in the $\mathrm{C}$-terminal region of the $\mathrm{C} 1$ protein (substituting CTT with CTA, both coding for leucine), which should have no effect on $\mathrm{C} 1$ function. To evaluate the effect of mutations within C2 on viral DNA replication, cloned plasmid DNAs capable of releasing wild-type and $c 2$ mutant viral genomes were transfected into protoplasts prepared from $N$. benthamiana suspension cells as previously described (Sunter et al. 2003). Both $c 2-4$ and $c 2-39$ mutant viruses were able to replicate in protoplasts, and viral DNA accumulated to levels comparable to wild-type virus by 8 days posttransfection, as determined by phosphorimager (Fig. 6). However, there is an initial two- to threefold reduction in the accumulation of mutant viral DNA relative to wild-type DNA between 3 and 5 days posttransfection (Fig. 6.). As the reduction in DNA accumulation was observed for both mutant viruses, we do not believe that the silent mutation introduced within $\mathrm{C} 1$ to generate the $c 2-4$ mutant has any significant effect on viral DNA replication.
A unique disease phenotype is associated with $c 2$ mutants in Arabidopsis and spinach.

To evaluate the role of SCTV C2 in viral pathogenesis, healthy $N$. benthamiana, Arabidopsis, spinach, and sugar beet plants were inoculated with Agrobacterium cultures containing tandem repeated copies of wild-type (Baliji et al. 2004) or $c 2$ mutant SCTV DNAs. Both c2-39 and c2-4 mutant viruses were infectious in all four plant species tested, and plants exhibited symptoms typical of a wild-type SCTV infection. Symptoms observed on $N$. benthamiana and sugar beet infected with wild-type or mutant SCTV viruses were indistinguishable, but distinct differences were observed in Arabidopsis and spinach plants infected with $c 2$ mutant viruses. Wild-type SCTV virus generally caused more severe symptoms in Arabidopsis (Fig. 7A), similar to that observed for Beet severe curly top virus (formerly called BCTV-CFH) infection (Lee et al. 1994), including severe stunting of the plants. Arabidopsis plants inoculated with either wild-type SCTV or $c 2$ mutant viruses began to develop symptoms 5 days postinoculation (dpi), indicating that the mutations had no detectable effect on the timing of symptom appearance. However, differences in the severity of disease were observed by $10 \mathrm{dpi}$, and so an Arabidopsis disease severity index (Table 2 and Fig. 7B) was developed, similar to that for other geminiviruses (Martin et al. 1999). Disease severity in Arabidopsis plants was measured in terms of disease incidence (percentage of inoculated plants that became infected) and observable phenotypes on newly developed bolts (flower stalks that emerge from rosette leaves). For disease incidence, 95\% of Arabidopsis plants (150 plants) inoculated with wildtype SCTV exhibited symptoms, whereas 89 and $85 \%$ of plants inoculated with $c 2-39$ (150 plants) and $c 2-4$ (150 plants) mutant viruses, respectively, displayed symptoms (data not shown). Although fewer plants become infected when inoculated with mutant viruses, the data indicates that overall infectivity remains high when inoculated with either wild-type or mutant viruses. This does not take into account the number of infected bolts per plant or the severity of symptoms observed, and there are significant differences in the observable phenotypes on newly developed bolts from plants infected with mutant viruses (Fig. 7B). We utilized five categories ranging from asymptomatic (Category 0) to the most severely diseased (Category 4) bolts (Table 2; Fig. 7B). When Arabidopsis plants were inoculated with wild-type SCTV, approximately $69 \%$ of bolts on infected plants exhibited symptoms that fall into the

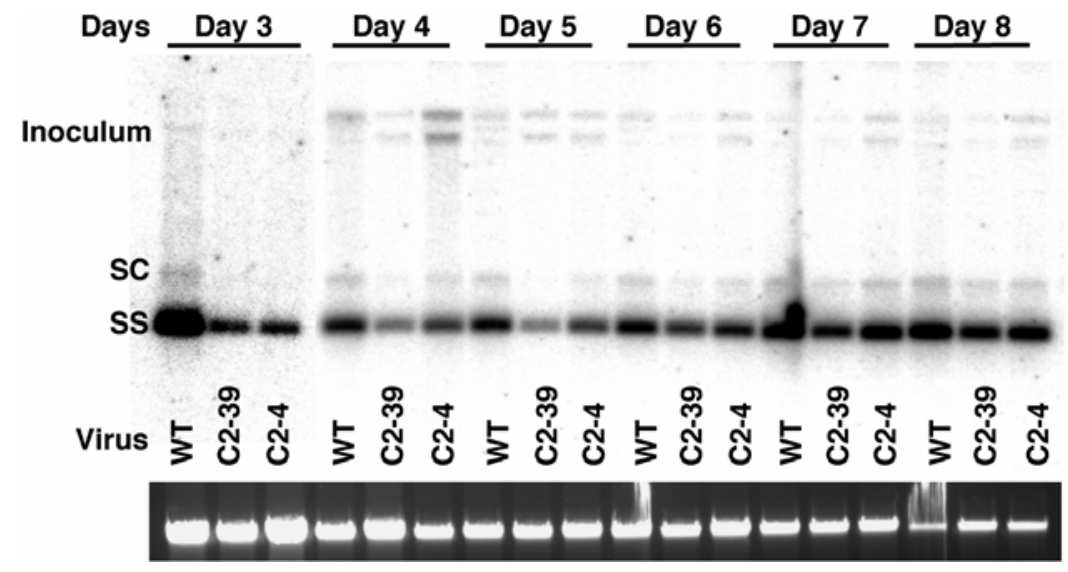

Fig. 6. Gel-blot hybridization of wild-type and mutant Spinach curly top virus (SCTV) DNA accumulation in protoplasts. Protoplasts prepared from Nicotiana benthamiana suspension cells were transfected with wild-type, $c 2-39$ mutant, or $c 2-4$ mutant SCTV DNA. Total DNA was isolated from protoplast extracts on consecutive days starting at 3 days postinoculation (dpi) and ending at 8 dpi. Following electrophoresis of total DNA ( $5 \mu \mathrm{g}$ ) and transfer to nitrocellulose membranes, the blot was hybridized with a probe specific for SCTV DNA and was analyzed by phosphorimager (7-day exposure). Input plasmid DNA, viral single-stranded (SS), and viral double-stranded supercoiled (SC) DNA forms are indicated on the left. A gel stained with ethidium bromide is shown below the blot as a loading control. 


\section{A}

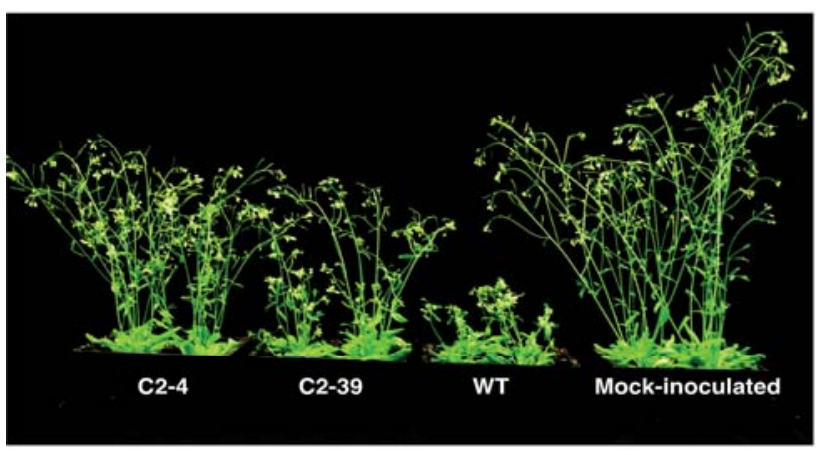

B

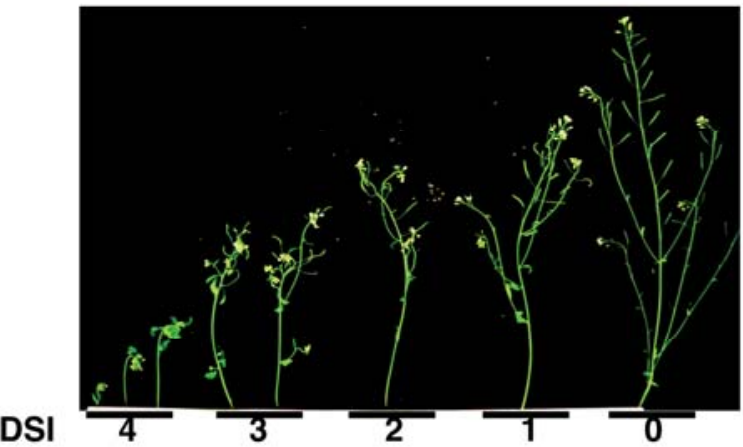

C

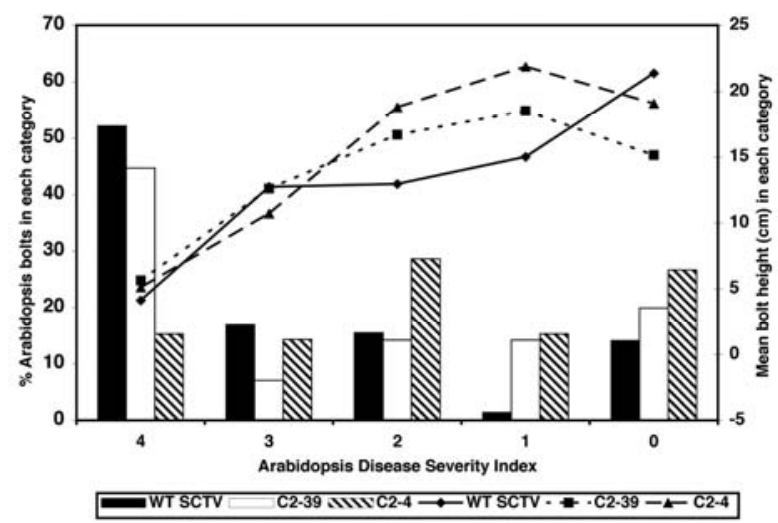

Fig. 7. Symptom phenotypes in infected Arabidopsis plants. Four- to fiveweek-old healthy Arabidopsis plants were agroinoculated with either wildtype or mutant Spinach curly top virus (SCTV). Inoculated plants were scored for the appearance of symptoms typical of an SCTV infection on systemically infected plants. A, Representative Arabidopsis plants agroinoculated with wild-type, $c 2-39$ mutant, or c2-4 mutant SCTV, as compared with a mock-inoculated asymptomatic plant at 10 days postinoculation. B, Phenotype of inoculated Arabidopsis bolts within each of the five categories outlined in the Arabidopsis disease severity index (Table 2). C, A graphical representation of the percentage of Arabidopsis bolts from plants infected with wild-type (278 bolts), c2-39 mutant (293 bolts), or $c 2-4$ mutant (309 bolts) SCTV, displaying symptom phenotypes within each category of the Arabidopsis disease severity index (bars). The lines represent mean bolt height within each category from plants inoculated with wild-type, $c 2-39$ mutant, or c2-4 mutant SCTV. most severe categories (Categories 3 and 4), including severe curling and stunting (Fig. 7B and C). Less than $15 \%$ of bolts exhibited mild symptoms when inoculated with wild-type SCTV. In contrast, only $29 \%$ of infected bolts on Arabidopsis plants infected with $c 2-4$ mutant virus exhibited the most severe symptoms (Categories 3 and 4), a two- to threefold reduction as compared with wild-type virus (Fig. 7B and C). Approximately $45 \%$ of bolts from infected plants remained asymptomatic or exhibited extremely mild symptoms (Categories 0 and 1 ), and bolts were generally longer than those of plants infected with wild-type virus (Fig. 7B and C). Interestingly, Arabidopsis plants infected with $c 2-39$ mutant virus exhibited an intermediate phenotype with approximately $51 \%$ of bolts exhibiting severe symptoms (Categories 3 and 4) and approximately $28 \%$ of bolts showing milder symptoms (Fig. 7B and C).

A similar result was obtained for infected spinach plants, although, unlike Arabidopsis, a significant number of spinach plants remained uninfected even with wild-type SCTV, but the reason for this is unknown. Only four disease severity categories were assigned (Table 3 ), but spinach plants infected with c2-4 mutant virus also exhibited reduced disease severity and infectivity when compared with plants infected with wild-type virus (Fig. 8A and B). In plants infected with wild-type SCTV,

Table 2. Arabidopsis disease severity index ${ }^{\mathrm{a}}$

\begin{tabular}{|c|c|c|}
\hline Category & Disease Severity & Phenotype \\
\hline 4 & Most severe & $\begin{array}{l}\text { Severe curling of bolts } \\
\text { Malformed inflorescence } \\
\text { Plants severely stunted } \\
\text { No laterals. }\end{array}$ \\
\hline 3 & Severe & $\begin{array}{l}\text { Curling of bolts } \\
\text { Malformed inflorescence } \\
\text { No laterals } \\
\text { Bolts grow longer than in Category } 4 .\end{array}$ \\
\hline 2 & Less severe & $\begin{array}{l}\text { Curling of siliques (curling }>180^{\circ} \text { ) } \\
\text { Laterals produced but all are infected } \\
\text { Bolts grow longer than in Category } 3 \text {. }\end{array}$ \\
\hline 1 & Mild & $\begin{array}{l}\text { Mild curling of siliques (curling }<180^{\circ} \text { ) } \\
\text { Some laterals remain healthy } \\
\text { Bolt height comparable to asymptomatic } \\
\text { bolt height. }\end{array}$ \\
\hline 0 & Asymptomatic & $\begin{array}{l}\text { Inoculated plants remain healthy } \\
\text { Bolts do not show symptoms }\end{array}$ \\
\hline
\end{tabular}

${ }^{a}$ Disease categories are based on the severity of symptoms observed in Arabidopsis bolts on plants agroinoculated with Spinach curly top virus. Five category ratings were used, ranging from asymptomatic (0) to severe stunting and curling (4).

Table 3. Spinach disease severity index ${ }^{a}$

\begin{tabular}{lll}
\hline Category & Disease Severity & \multicolumn{1}{c}{ Phenotype } \\
\hline 3 & Most severe & $\begin{array}{l}\text { No flowering } \\
\text { Plants extremely stunted } \\
\text { Young leaves extremely deformed, } \\
\text { rigid, and chlorotic } \\
\end{array}$ Some flowering \\
& & $\begin{array}{l}\text { Plants stunted relative to asymptomatic } \\
\text { Young leaves severely curled and } \\
\text { chlorotic. }\end{array}$ \\
& & Inflorescence mostly straight \\
& & Very few young leaves curled \\
& & Plants comparable to asymptomatic \\
& & phenotype. \\
& & Inoculated plants remain healthy. \\
& & Leaves and inflorescence do not show \\
& & symptoms. \\
\hline
\end{tabular}

${ }^{a}$ Disease categories are based on the severity of symptoms observed in spinach plants agroinoculated with Spinach curly top virus. Four category ratings were used, ranging from asymptomatic (0) to severe stunting and curling (3). 
approximately $58 \%$ of infected spinach plants exhibited severe symptoms (Categories 2 and 3), manifested by severe curling and stunting (Fig. 8A and B). In the case of spinach plants infected with $c 2-4$ mutant virus, only approximately $34 \%$ of infected plants exhibited severe symptoms, an approximately twofold reduction relative to wild-type virus (Fig. 8B). However, almost $50 \%$ of the plants inoculated with $c 2-4$ mutant virus remained asymptomatic, as compared with only $35 \%$ in plants infected with wild-type SCTV (Fig. 8B). As with Arabidopsis, spinach plants infected with $c 2-39$ mutant virus display an intermediate phenotype (Fig. 8A and B).

These results indicate that a functional $\mathrm{C} 2$ gene product in SCTV is not absolutely required for replication or systemic spread. However, C2 does appear to have some quantitative effects on symptom production in certain hosts, as mutations result in a shift toward less severe symptoms.

\section{Viral DNA accumulation is correlated} with reduced severity in Arabidopsis and spinach.

Total DNA was isolated from the most severely infected tissue in N. benthamiana, Arabidopsis, and spinach plants, and viral DNA accumulation was analyzed by DNA gel-blot hybridization. To determine whether viral DNA accumulation was correlated with disease severity, DNA gel-blot hybridiza-

\section{A}

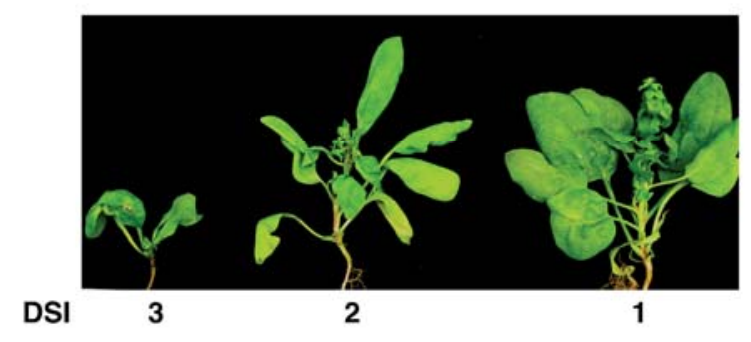

B

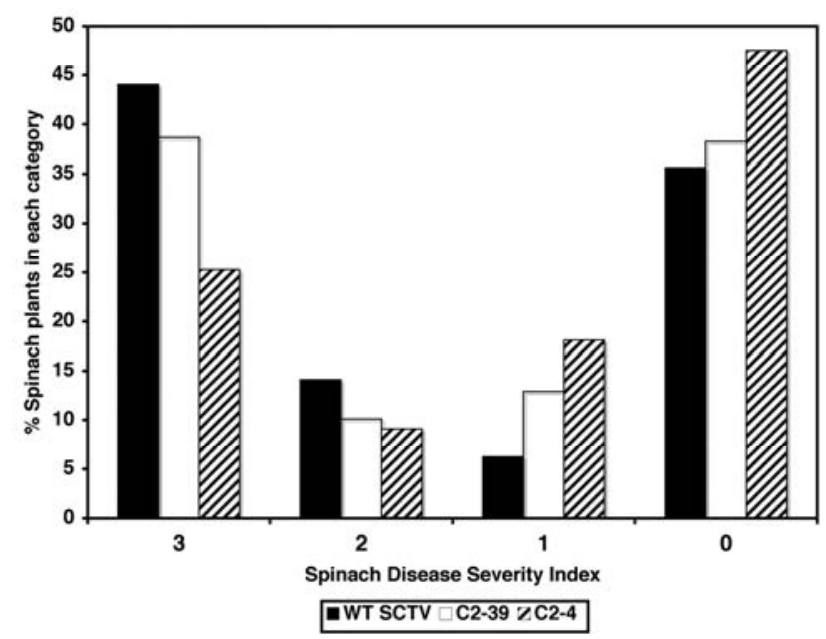

Fig. 8. Symptom phenotypes in infected spinach plants. Three- to fourweek-old spinach plants agroinoculated with either wild-type or mutant Spinach curly top virus (SCTV). Inoculated plants were scored for the appearance of symptoms typical of an SCTV infection on systemically infected plants. A, Phenotype of infected plants at 10 days postinoculation for three of the disease categories outlined in the spinach disease severity index (Table 3). Mock-inoculated asymptomatic plants are not shown. B, A graphical representation of percentage of spinach plants inoculated with either wild-type, $c 2-39$ mutant, or $c 2-4$ mutant SCTV (100 plants each) displaying symptom phenotypes within each category of the spinach disease severity index (bars). tion analysis of spinach plants displaying symptoms from different disease categories infected with wild-type or $c 2$ mutant viruses was performed. A two- to threefold reduction in the amount of viral DNA, as determined by phosphorimager, was observed in plants exhibiting mild symptoms (Category 1) as compared with the most severely infected spinach plants (Category 3). This was observed in plants infected with either wildtype or $c 2$ mutant virus. However, no difference in accumulation of viral DNA was observed in spinach plants infected with wild-type or mutant viruses within any severe disease category (Fig. 9). Similar results were obtained for Arabidopsis plants infected with wild-type or mutant SCTV viruses (data not shown), suggesting that viral DNA accumulation correlates with symptom severity. In all cases, viral DNA was not detected in asymptomatic tissue (Fig. 9, lane 1) or mock-inoculated plants (data not shown). The infectivity of SCTV $c 2$ mutants was not a result of reversion to wild-type virus, as viral DNA from plants infected with $c 2$ mutant viruses retained the $X b a \mathrm{I}$ site introduced within the C2 ORF (data not shown).

\section{The SCTV C2 gene product interacts} with Arabidopsis AKIN11 and adenosine kinase.

BCTV L2 causes enhanced susceptibility to DNA and RNA virus infection when expressed as a transgene (Sunter et al. 2001), and the susceptibility phenotype is attributable to the interaction with two cellular kinases, AKIN11 and ADK2 (Hao et al. 2003; Wang et al. 2003). Our results show that viruses containing mutations within the SCTV C2 ORF cause milder

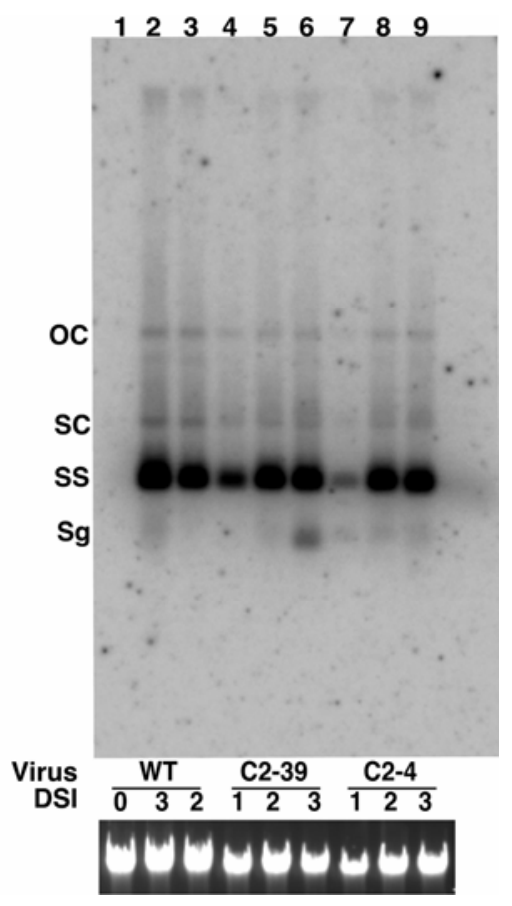

Fig. 9. Accumulation of wild-type and mutant Spinach curly top virus (SCTV) DNA in infected spinach plants. Total DNA $(5 \mu \mathrm{g})$ from spinach plants agroinoculated with either wild-type or mutant SCTV, 10 days postinoculation, was transferred to nitrocellulose membranes and was hybridized with a probe specific for SCTV DNA. Replicating DNA was detected by phosphorimager (7-day exposure). Viral single-stranded (SS), double-stranded supercoiled (SC), and open circle (OC) DNA forms are indicated on the left. A DNA form present in some infected plant samples with electrophoretic mobility greater than that of viral ssDNA represents de novo-generated subgenomic ( $\mathrm{Sg}$ ) DNA forms of the viral genome in which portions of the genome have been deleted (Baliji et al 2004). DNA samples were isolated from tissue representative of each disease severity category from plants inoculated with wild-type (lanes 1 to 3), c2-39 mutant (lanes 4 to 6), or $c 2-4$ mutant (lanes 7 to 9) SCTV. A gel stained with ethidium bromide is shown below the blot as a loading control. 
symptoms in Arabidopsis and spinach plants. As a potential interaction between SCTV C2 and AKIN11 or ADK2 could play an important role in disease development, we tested the ability of wild-type or truncated SCTV C2 proteins to interact with these two proteins, using a yeast two-hybrid system. Yeast growth in synthetic complete (SC) medium lacking histidine, indicative of an interaction, was supported when cells expressed both AKIN11 and a truncated SCTV C2 (C2-39) protein (Table 4). A similar result was obtained when yeast cells expressed both ADK2 and C2-39. This suggests that the N-terminal 38 amino acids of SCTV C2 are sufficient to interact with AKIN11 and ADK2. However, in both cases, the interaction was not as efficient as wild-type $\mathrm{C} 2$ protein (Table 4). An interaction was also detected in yeast cells expressing AKIN11 or ADK2 and truncated BCTV L2 proteins, consisting of the N-terminal 72 (L2-1) or 74 (L2-2) amino acids (Table 4). Viruses containing these $l 2$ mutations remain infectious on $N$. benthamiana plants (Hormuzdi and Bisaro 1995). As expected, a truncated SCTV $\mathrm{C} 2$ consisting of the $\mathrm{N}$-terminal three amino acids $(\mathrm{C} 2, \mathrm{C} 3$, and C4) was unable to interact with AKIN11 or ADK2 in the yeast two-hybrid system (Table 4). A possible relationship between this interaction and disease severity is presented in the discussion.

Table 4. Yeast two-hybrid analysis ${ }^{\mathrm{a}}$

\begin{tabular}{llc}
\hline Bait & \multicolumn{1}{c}{ Prey } & Interaction $^{\mathbf{b}}$ \\
\hline AKIN11 & WT TGMV AL2 & ++ \\
AKIN11 & WT BCTV L2 & ++ \\
AKIN11 & WT SCTV C2 & + \\
AKIN11 & SCTV C2-39 & $+/$ \\
AKIN11 & SCTV C2-4 & - \\
AKIN11 & BCTV L2-1 & ++ \\
AKIN11 & BCTV L2-2 & ++ \\
ADK2 & WT TGMV AL2 & + \\
ADK2 & WT BCTV L2 & + \\
ADK2 & WT SCTV C2 & + \\
ADK2 & SCTV C2-39 & $+/$ \\
ADK2 & SCTV C2-4 & - \\
\hline
\end{tabular}

${ }^{\mathrm{a}}$ Interaction of wild-type and mutant forms of geminivirus AL2, L2, and C2 protein with the cellular kinases AKIN11 and ADK2. The indicated bait proteins were expressed as GAL4 DNA binding domain fusions, and prey proteins were expressed as GAL4 activation domain fusions in Yeast Y190 cells.

${ }^{\mathrm{b}}$ A positive interaction was indicated by the ability of Y190 cells transformed with both bait and prey constructs to grow on synthetic complete (SC) medium lacking histidine and containing $50 \mathrm{mM} 3$-aminotriazole. As an additional indicator of a positive interaction, yeast cells were monitored for LacZ activity (blue color) using filter lift assays. Symbols indicate: (-), no interaction; (+/-), weak interaction, color developed overnight; (+) moderate to strong interaction, color developed after approximately $2 \mathrm{~h} ;(++)$, strong interaction, color developed within minutes to $2 \mathrm{~h}$.

\section{DISCUSSION}

We have identified a number of viral and complementary sense transcripts in SCTV-infected plants, confirming a bidirectional transcription strategy for SCTV (Fig. 10). The most abundant RNA maps to the virion sense and is comparable in size and location to that observed in BCTV (Frischmuth et al. 1993). High-resolution mapping of the virion sense transcription unit reveals multiple overlapping transcripts with two major 5' termini. One 5' end mapped upstream of V1, V2, and V3 and could potentially encode all three proteins, whereas the second $5^{\prime}$ end mapped upstream of V1 and V2 and could potentially encode both of these proteins (Fig. 3C). Analysis of SCTV sequences indicates the presence of TATA box sequences approximately 20 to $30 \mathrm{nt}$ upstream of both $5^{\prime}$ ends (Fig. 3C), suggesting that these represent authentic transcription start sites for the virion sense transcription unit. Additional products detected possibly reflect premature termination of the reverse transcriptase due to secondary structure, cleavage by DNaseI at sensitive sites, the presence of multiple start sites, or a combination of these. A single $3^{\prime}$ end was located between the converging V1 and C3 genes (Figs. 5C and 10). This site is located at an optimal distance downstream of a consensus poly (A) termination signal that overlaps the double translational stop codon for V1 (UAAUAAA), suggesting that it represents the authentic $3^{\prime}$ end for the virion sense transcripts (Fig. 3C). The predicted size of RNAs initiating at the $5^{\prime}$ and $3^{\prime}$ ends mapped here is consistent with the $1.1-\mathrm{kb}$ virion sense RNA detected in SCTV-infected tissue (Fig. 2A). A similar arrangement has been observed for BCTV and MYMV DNA A virion sense transcripts and could reflect the requirement for different viral gene products at different stages in the viral life cycle (Frischmuth et al. 1991; Shivaprasad et al. 2005).

Two complementary sense transcripts were identified in SCTV-infected plants, and the large, approximately $1.7-\mathrm{kb}$ transcript is comparable in size and position to that identified in BCTV (Frischmuth et al. 1993) and several begomoviruses (Frischmuth et al. 1991; Mullineaux et al. 1993; Sunter and Bisaro 1989; Sunter et al. 1989; Townsend et al. 1985) and most likely encodes the $\mathrm{C} 1$ protein. High-resolution mapping identified a predominant $5^{\prime}$ end located upstream of the C1 ORF (Fig. 4C) within the large intergenic region (LIR). A TATA sequence is located 20 to $30 \mathrm{nt}$ upstream of the $5^{\prime}$ end, which suggests this is an authentic transcription initiation site for the $\mathrm{C} 1$ transcription unit. Two predominant $3^{\prime}$ termination sites were mapped downstream of $\mathrm{C} 3$, but only one is at an optimal distance downstream of a consensus poly (A) termination signal (Fig. 5C). The $1.7-\mathrm{kb}$ complementary sense transcript identified in SCTVinfected plants is consistent with RNAs initiating at the $5^{\prime}$ ends and terminating at the $3^{\prime}$ ends mapped in this study. The rele-

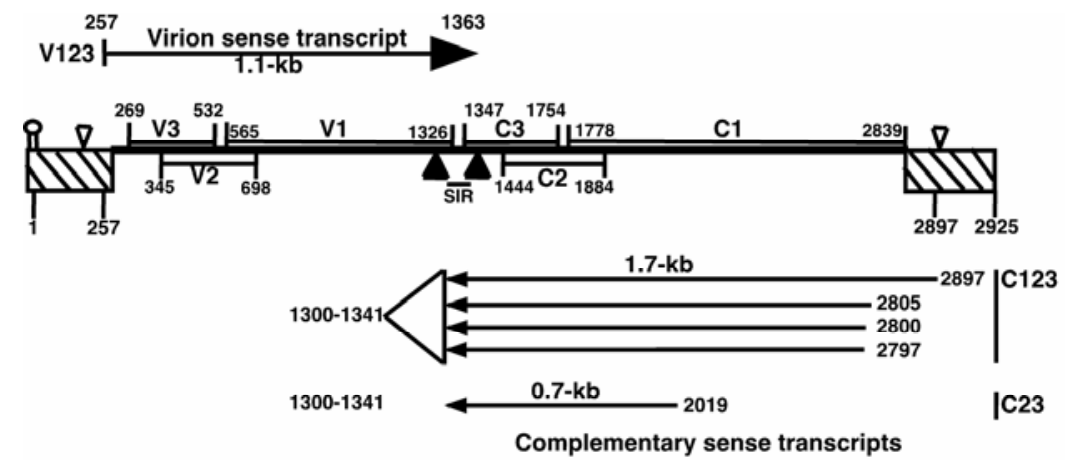

Fig. 10. Transcription map of Spinach curly top virus (SCTV) RNAs. The diagram shows, in linear form, the map positions of major virion and complementary sense transcripts (arrows) relative to the large (hatched boxes) and small intergenic regions. The SCTV virion and complementary sense open reading frames, TATAA sequences (open triangles), and polyadenylation signals (shaded triangles) are also indicated. 
vance of additional $5^{\prime}$ ends mapped just downstream of the $\mathrm{C} 1$ translation start site is unknown, but similar transcription initiation sites were also detected in TGMV- and MYMV-infected plants (Shivaprasad et al. 2005; Sunter and Bisaro 1989).

Two $5^{\prime}$ ends were mapped within the C1 ORF, upstream of both $\mathrm{C} 2$ and $\mathrm{C} 3$ (Fig. 5C), but only one $5^{\prime}$ end is located at an optimal distance of approximately $30 \mathrm{bp}$ from a consensus TATA box (Fig. 5C). Three minor start sites detected between the $\mathrm{C} 2$ and $\mathrm{C} 3$ ATG codons could potentially encode C3 alone (Fig. 5C) and are similar to sites reported for transcripts derived from MYMV DNA A (Shivaprasad et al. 2005). The relevance of these additional start sites is unknown, but their presence in SCTV and a number of begomoviruses might suggest that different transcripts can be generated using different $5^{\prime}$ initiation sites with different $3^{\prime}$ ends to regulate $\mathrm{C} 2$ and $\mathrm{C} 3$ expression. Alternatively, this region is relatively AT-rich (Fig. 5C), which could contribute to the observed variability of $5^{\prime}$ ends. The $3^{\prime}$ termini of viral and complementary sense transcripts overlap each other by approximately $60 \mathrm{nt}$, similar to that observed for other geminiviruses (Frischmuth et al. 1991; Mullineaux et al. 1993; Sunter and Bisaro 1989; Sunter et al. 1989; Townsend et al. 1985). Although the leftward and rightward transcripts overlap only in a short region (Fig. 10), aberrant read-through transcription on a circular viral DNA could potentially lead to production of longer antisense transcripts that could be a trigger for RNA silencing (Akbergenov et al. 2006; Shivaprasad et al. 2005).

Having identified transcripts capable of coding for $\mathrm{C} 2$, we then analyzed the role of C2 in SCTV pathogenesis. SCTV c2 mutant viruses cause different disease phenotypes in infected plants. One mutation (c2-39) is very similar to those previously constructed in BCTV (Hormuzdi and Bisaro 1995; Stanley et al. 1992). The second mutation (c2-4) essentially ensures that no functional $\mathrm{C} 2$ protein is produced and differs from all previous BCTV $l 2$ mutants generated (Hormuzdi and Bisaro 1995; Stanley et al. 1992). Both $c 2$ mutant viruses of SCTV were able to infect spinach, sugar beet, $N$. benthamiana, and Arabidopsis plants, demonstrating that the $\mathrm{C} 2$ gene product is not required for infectivity.

It has been shown that $N$. benthamiana plants infected with BCTV mutants capable of expressing the first 72 amino acids of L2 recover from the early onset of curly top disease, which is correlated with a reduction in DNA levels (Hormuzdi and Bisaro 1995). In the current study, we did not observe any recovery phenotype in $N$. benthamiana plants infected with either wildtype or mutant SCTV viruses. Also, virulence of both $c 2$ mutant viruses in $N$. benthamiana was equivalent to that of wild-type virus, as determined by the infectious dose required to infect half the plants $\left(\mathrm{ID}_{50}\right)$ (data not shown), which were carried out using approximately 100 plants as described by Sunter and associates (2001). However, distinct phenotypes were evident in Arabidopsis and spinach plants infected with c2-4 or c2-39 mutant virus. Plants infected with $c 2-4$ mutant virus generally displayed milder symptoms than plants inoculated with wild-type virus. In contrast, plants infected with $c 2-39$ mutant virus produced an intermediate phenotype. In Arabidopsis, the majority of plants became infected when inoculated with either wild-type or mutant SCTV virus, but in spinach a significant number of plants remained asymptomatic. This could represent a difference in the efficiency of agro-infection between the two hosts or differences in the host response to viral infection.

Viral DNA accumulation in the most severely infected plant tissue was very similar for both wild-type and mutant viruses. This suggests that $c 2$ mutant viruses have similar abilities to replicate and that differences in the ability of these viruses to infect Arabidopsis or spinach plants may be due to differences in the ability to produce a functional $\mathrm{C} 2$ protein. Our results demonstrate that truncated SCTV C2 (c2-39) and BCTV L2 (L2-1 and L2-2) proteins can interact with AKIN11 and ADK2 in the yeast two-hybrid system, which might lead to the conclusion that differences in phenotypes are a consequence of this interaction. In all cases, the C2-39 protein exhibited a weaker interaction with AKIN11 and ADK2 than that of wildtype $\mathrm{C} 2$, as determined by yeast two-hybrid analysis. As a similar truncated BCTV L2 protein also displayed reduced growth on SC medium lacking histidine, this weaker interaction could result in a reduced ability to suppress host defense responses via these interactions (Hao et al. 2003; Wang et al. 2003). It is possible that the milder symptoms detected in plants infected with c2-4 mutant virus is a consequence of the absence of a functional C2 protein to interact with AKIN11 and ADK2. This is supported by the intermediate phenotype observed in plants infected with $c 2-39$ mutant virus, as compared with plants infected with wild-type or $c 2-4$ mutant virus. Another possible explanation for the milder symptoms detected in plants infected with $c 2-4$ mutant virus is differences in replication kinetics. In protoplasts, $c 2-4$ mutant virus accumulates to lower levels than wild-type virus 3 days posttransfection, but no difference in accumulation is detected 8 days posttransfection. This delay could be sufficient to allow the host to suppress the infection, especially in the absence of a functional C2 protein. A similar difference in viral DNA accumulation is also observed in protoplasts transfected with $c 2-39$ mutant virus. As this virus can express a truncated protein of 38 amino acids capable of interacting with AKIN11 and ADK2, albeit inefficiently, this could allow the virus to suppress the host defense response but not as efficiently as wild type, resulting in an intermediate phenotype. We cannot, therefore, rule out that the milder symptoms observed in plants infected with $c 2-4$ mutant virus is a consequence of a combination of defects in replication and suppression of host defenses.

An alternative possibility is that the $\mathrm{C} 2$ protein plays a role in movement of the virus, resulting in reduced symptom severity. However, as mutant and wild-type viruses appear to replicate to equivalent levels in tissue exhibiting comparable symptoms, we do not believe this to be the case. Another possibility is that the SCTV C2 gene product could regulate expression of virion sense genes, as observed for several AL2 homologs in begomoviruses (Sunter et al. 1994). However, SCTV C2 is unable to activate the TGMV $C P$ promoter (S. Baliji and G. Sunter, unpublished observation). This leads us to believe that SCTV C2 does not play a role in activating viral gene expression, although the possibility that it may have some quantitative effect cannot be ruled out. Taken together, the data presented here suggests that $\mathrm{C} 2$ plays an important role in SCTV pathogenesis.

\section{MATERIALS AND METHODS}

\section{DNA techniques.}

The map locations and restriction endonuclease sites cited here refer to the published DNA sequence of SCTV (Baliji et al. 2004). All restriction endonucleases and DNA-modifying enzymes were used as recommended by the manufacturers. DNA and RNA manipulations, RT-PCR, DNA gel-blot hybridization, and RNA gel-blot hybridization were performed essentially as described by Ausubel and associates (2001) unless otherwise stated. All sequence alterations were confirmed by DNA sequencing (The Plant-Microbes Genomic Facility, Ohio State University, Columbus, OH, U.S.A.).

\section{DNA constructs.}

Plasmids containing tandemly repeated copies of SCTV DNA genome in both pUC (pSCTV-D) and binary plasmid 
(pSCTV-WT) vectors have been previously described (Baliji et al. 2004). Constructs are capable of releasing replicating SCTV DNA, primarily by a rolling circle replicative mechanism (Stenger et al. 1991). Two mutations were created within the C2 ORF (C2-39 and C2-4). Mutation C2-39 was generated as follows. A 2,246-bp fragment of SCTV DNA was amplified with the primers $\mathrm{ClaI}$ and C2-39a (Table 1), using pSCTV-D as template. Primer C2-39a introduces an $\mathrm{XbaI}$ site within the C2 ORF at nucleotide coordinates 1,773 to 1,768 . The resulting PCR product was digested with $\mathrm{XbaI}$ and HindIII (Fig. 1) and was ligated to similarly digested pUC119 generating a partial C2 mutant (pUC-C2m), containing SCTV sequences from nucleotide 1,785 to 2,464 , including the LIR (Fig. 1). Using primers M13F and C2-39b, the latter of which also introduces an $\mathrm{XbaI}$ site within the $\mathrm{C} 2 \mathrm{ORF}$ at nucleotide coordinates 1,773 to 1,768 , a 100-bp fragment was amplified by PCR from pSCTV-D. The resulting product contains SCTV sequences from nucleotide 1,755 to the EcoRI site at nucleotide 1,851 . DNA was digested with $X b a \mathrm{I}$ and EcoRI and was ligated to similarly digested pUC-C2m, generating a complete $\mathrm{C} 2 \mathrm{ORF}$ (pUC-C2mFL). This mutation created an $\mathrm{XbaI}$ restriction site at nucleotides 1,773 to 1,768 of SCTV genome and introduced the UAG stop codon. A 2,009-bp fragment containing SCTV sequences from nucleotides 1,851 to 2,767 with the LIR and C2 mutation was then amplified by PCR, using M13F and M13R primers (Table 1) with pUC-C2 $\mathrm{mFL}$ as template. DNA was cloned into the EcoRI site of pMON521 (a binary plasmid vector) made blunt-ended by treatment with mungbean nuclease. The resulting DNA ( $\mathrm{p} 521-\mathrm{C} 2 \mathrm{~m}$ ) contains 0.7 copies of the SCTV genome from the EcoRI site at nucleotide 1,851 and containing the $\mathrm{C} 2$ and $\mathrm{C} 3 \mathrm{ORF}$ and all the virion sense ORFs, along with one copy each of the large and small intergenic regions (Fig. 1). A 1,659-bp fragment from EcoRI to SnaBI (nucleotide 1,851 to 585 ), restricted from a monomeric SCTV genome (Fig. 1) that contains a second copy of LIR, was ligated to $\mathrm{p} 521-\mathrm{C} 2 \mathrm{~m}$ with comparable ends, generating 1.25 copies of the SCTV genome with a single copy of C2 mutation (pSCTV C2-39) and two LIR sequences.

To generate the $c 2-4$ double mutant, $\mathrm{C} 2-4 \mathrm{~m}$ and $B g l \mathrm{II}$ primers (Table 1) were used to amplify a 609-bp fragment, from nucleotide 2,491 to 1,882, using pSCTV C2-39 as template. The $\mathrm{C} 2-4 \mathrm{~m}$ primer introduces a stop codon at the beginning of the C2 ORF after three amino acids at nucleotide 1,874. The amplified product, containing both mutations at nucleotides 1,771 and 1,874, was restricted with EcoRI and $B g l \mathrm{II}$ and was used to replace the corresponding DNA fragment of pSCTV C2-39. The resulting DNA construct (pSCTV C2-4) contains 1.25 copies of the SCTV genome with a single copy of both C2 mutations and two LIR sequences. All DNA constructs were mobilized into Agrobacterium tumefaciens GV3111SE by triparental mating (Rogers et al. 1987) and were used for agroinoculation.

\section{Protoplast transfection.}

Protoplasts were prepared from an $N$. benthamiana suspension culture cell line and were transfected with various plasmid DNAs as described (Sunter and Bisaro 2003). After incubation in the dark for 3 to 8 days, DNA was isolated from protoplast extracts using TNE (100 mM Tris- $\mathrm{HCl}, \mathrm{pH} 8.0,200 \mathrm{mM} \mathrm{NaCl}$, 10 mM EDTA, pH 8.0, 1\% SDS, $1 \% \beta$-mercaptoethanol) and was treated with RNaseA. Total DNA $(5 \mu \mathrm{g})$ was electrophoresed through $1 \%$ Tris-acetate-EDTA agarose gels, transferred to Protran pure nitrocellulose membranes (Schleicher and Schuell, Keene, NH, U.S.A.), and was immobilized by UV cross-linking (UV-Strata linker 1800; Stratagene, La Jolla, CA, U.S.A.). SCTV accumulation in transfected protoplasts was detected by hybridization to a ${ }^{32} \mathrm{P}$-labeled probe specific for
SCTV DNA (Baliji et al. 2004), generated by random priming (DECA Prime II labeling kit; Ambion, Austin, TX, U.S.A.). SCTV DNA levels were quantified by phosphorimager analysis (Molecular Imager FX; Bio-Rad, Hercules, CA, U.S.A.).

\section{Plant inoculation.}

Healthy N. benthamiana, Arabidopsis thaliana (Columbia ecotype), spinach (Spinacea oleracea var. viroflay), and sugar beet (Beta vulgaris L.) were agroinoculated with Agrobacterium cultures containing either tandemly repeated copies of wild-type or mutant SCTV DNA, using a standard dose (optical density at $600 \mathrm{~nm}=1.0$ ) as described previously (Baliji et al. 2004). Inoculated plants were scored for the appearance of symptoms typical of an SCTV infection on systemically infected tissue on a daily basis. DNA was isolated from infected and healthy mock-inoculated plants $10 \mathrm{dpi}$ and was analyzed for SCTV replication and DNA accumulation as described for protoplast experiments.

\section{RNA isolation.}

Total RNA was isolated from infected and healthy mockinoculated plant tissue, using Plant RNA Reagent as described by the manufacturer (Invitrogen, Carlsbad, CA, U.S.A.), and was treated with DNaseI (Ambion). Total RNA free from contaminating DNA was stored at $-80^{\circ} \mathrm{C}$. Total RNA $(10$ to $20 \mu \mathrm{g})$ at a concentration of 1 to $2 \mathrm{mg} / \mathrm{ml}$ was heat-denatured and fractionated on oligo (dT) cellulose columns as described previously (Sunter et al. 1989). Eluted poly (A) ${ }^{+}$RNA was resuspended in diethylpyrocarbonate-treated water and was stored at $-80^{\circ} \mathrm{C}$.

\section{Northern blot hybridization.}

Total $(10 \mu \mathrm{g})$ and poly $(\mathrm{A})^{+}(0.5 \mu \mathrm{g})$ RNA from infected, and healthy mock-inoculated plant tissues was analyzed on denaturing formaldehyde agarose gels (1.2\%), transferred onto Protran pure nitrocellulose membranes (Schleicher and Schuell) as described (Sunter et al. 2001), and was immobilized by UV cross-linking (UV-Strata linker 1800, Stratagene). To detect viral and complementary sense RNAs, membranes were hybridized to ${ }^{32} \mathrm{P}$-labeled riboprobes generated from an SCTV clone in pGEM5Zf+ (pSCTV-5Z), using either SP6 (complementary sense) or T7 (viral sense) RNA polymerase (Riboprobe systems; Promega, Madison, WI, U.S.A.).

\section{S1 nuclease protection.}

An 837-bp DNA probe fragment spanning the LIR of SCTV (nucleotides 2,745 to 657) was generated by PCR using V1Pxt and C1Pxt primers (Table 1) with pSCTV-D as template. The amplified DNA fragment was treated with calf intestinal alkaline phosphatase (CIAP) and was labeled with $\gamma^{32} \mathrm{P}$-ATP, using T4 polynucleotide kinase (T4 PNK). Labeled DNA was restricted with EcoICRI and the resulting 696- or 141-bp DNA fragments gel-isolated, to map either the virion or complementary sense transcripts, respectively. Poly $(\mathrm{A})^{+}$RNA was hybridized to each probe and was treated with $S_{1}$ nuclease as described previously (Sunter et al. 1989). $S_{1}$-resistant DNA was analyzed on $6 \%$ polyacrylamide sequencing gels and was sized against ${ }^{32} \mathrm{P}$-labeled fragments from $\Phi \mathrm{X} 174$ DNA digested with HinfI.

\section{Primer extension.}

Total RNA (10 to $20 \mu \mathrm{g}$ ) from healthy and SCTV-infected $N$. benthamiana leaf tissue was primed with ${ }^{32} \mathrm{P}$-labeled synthetic oligomers $\left(2 \times 10^{6}\right.$ to $\left.3 \times 10^{6} \mathrm{cpm}\right)$ and was extended using M-MuLV reverse transcriptase as described (Sunter et al. 1989). The primers used along with coordinates are given in Table 1. V1Pxt and V23Pxt primers, complementary to nucleo- 
tides 657 to 638 and 444 to 425 , respectively, were used to map the $5^{\prime}$ ends of the virion sense transcription unit. C1Pxt primer, complementary to nucleotides 2,745 to 2,764 , was used to locate the $5^{\prime}$ termini of the $1.7-\mathrm{kb}$ transcript. The C2Pxt and C3Pxt primers, complementary to nucleotides 1,956 to 1,975 and 1,689 to 1,708 respectively, were used to identify the $5^{\prime}$ ends of the $0.7-\mathrm{kb}$ transcript. All primers $(0.2$ pm each) were labeled at their $5^{\prime}$ end, using $\gamma^{32}$ P-ATP and T4 PNK. Labeled primers were purified on spin columns containing Sephadex G50 and were stored at $-20^{\circ} \mathrm{C}$. Primer extension products were recovered and analyzed on $6 \%$ polyacrylamide sequencing gels and were sized against ${ }^{32} \mathrm{P}$-labeled fragments from $\Phi X 174$ DNA digested with HinfI.

\section{cRT-PCR and RLM-RACE.}

cRT-PCR was performed essentially as described (Shivaprasad et al. 2005). Briefly, poly (A) ${ }^{+}$RNA isolated from SCTV-infected $N$. benthamiana leaves was treated with CIAP to remove the 5' phosphate group of noncapped mRNAs and any residual DNA fragments. Following treatment with tobacco acid pyrophosphatase to remove the $5^{\prime}$ phosphate group of capped mRNAs, T4 RNA ligase was used to circularize the resulting decapped transcripts. Circularized RNA was reverse transcribed, using random primers (Invitrogen) prior to PCR using specific primer combinations (Table 1) to simultaneously amplify both the $5^{\prime}$ and $3^{\prime}$ ends of SCTV complementary sense transcripts.

RLM-RACE was performed according to the manufacturer's instructions (Ambion). Poly (A) ${ }^{+}$RNA isolated from SCTVinfected $N$. benthamiana leaves was treated as described above for cRT-PCR, except that T4 RNA ligase was used to ligate a synthetic 5' RNA adapter primer (Table 1) to decapped mRNA. The resulting RNA was reverse transcribed, and PCR was performed with specific primer combinations (Table 1) to amplify $5^{\prime}$ termini of virus-specific transcripts.

For both techniques, PCR products were purified by gel extraction, were cloned into pGEMT-easy vector (Promega), and individual clones were sequenced.

\section{3' RACE.}

Poly (A) ${ }^{+}$RNA (100 ng) from SCTV-infected $N$. benthamiana leaf tissue was reverse transcribed with an oligo (dT) adapter primer (Table 1), and cDNA was used in PCR with primers specific for the $3^{\prime}$ ends of virion and complementary sense SCTV transcripts (Table 1). The $3^{\prime}$ cDNA ends of virion sense transcripts were amplified with the R4 and oligo(dT) adapter primer pair (Table 1). The 3' cDNA ends of complementary sense transcripts were amplified with either the $\mathrm{C} 2$ ORF $5^{\prime}$ and oligo(dT) adapter or the C3 ORF 5' and oligo(dT) adapter primer pairs (Table 1). Amplified products were cloned into pGEMT-easy (Promega), and DNA was analyzed by sequencing of individual cDNA clones.

\section{Yeast two-hybrid assay.}

Experiments to assess the interaction of SCTV C2 with AKIN11 and ADK2 were performed essentially as described previously (Hao et al. 2003). Bait constructs were expressed as GAL4 DNA binding domain (amino acids 1 to 147) fusion proteins, and prey constructs were expressed as GAL4 activation domain fusion proteins. The SCTV C2 ORF (444 nt) was amplified by PCR using C2 ORF-specific primers (Table 1). The resulting PCR product was cleaved with either NdeI and PstI or NdeI and XhoI (all shown in bold in Table 1) and was inserted into similarly cleaved pAS2 (Bait) or pACT2 (Prey) yeast vectors, respectively. A 1.5-kb DNA fragment containing the complete AKIN11 coding region was amplified from RNA isolated from healthy Arabidopsis by RT-PCR using AKIN11 ORF-specific primers (Table 1). The product was cleaved with
NcoI and BamHI (shown in bold in Table 1) and was inserted into similarly restricted pAS2 and pACT2 yeast vectors. Plasmid DNA containing the ADK2 coding region in pAS2 was provided by D. M. Bisaro and has been described previously (Wang et al. 2003). Plasmids containing a wild-type BCTV L2 or TGMV AL2 coding region in yeast two-hybrid vectors have been previously described (Hao et al. 2003). Mutations were introduced into the BCTV L2 coding region to generate DNAs capable of expressing truncated proteins of 72 (L2-1) and 74 (L2-2) amino acids (Hormuzdi and Bisaro 1995). Wild-type and mutant L2 sequences were amplified by PCR and were cloned into pACT2 as described (Hao et al. 2003). A positive interaction was indicated by the ability of Y190 yeast cells cotransformed with bait and prey plasmids to grow on synthetic medium lacking histidine and containing $50 \mathrm{mM} 3$-aminotriazole. The medium also lacked leucine and tryptophan for maintenance of expression plasmids. Additional confirmation of interactions was obtained by assessing $\beta$-galactosidase activity using a filter lift assay.

\section{ACKNOWLEDGMENTS}

The research was supported by a National Institutes of Health Minority Biomedical Research Support/Support of Competitive Research grant (GM-08194). We thank C.-Y. Shung, G. Lacatus, and J. Tu for critical reading of the manuscript.

\section{LITERATURE CITED}

Akbergenov, R., Si-Ammour, A., Blevins, T., Amin, I., Kutter, C., Vanderschuren, H., Zhang, P., Gruissem, W., Meins, F., Hohn, T., and Pooggin, M. M. 2006. Molecular characterization of geminivirusderived small RNAs in different plant species. Nucleic Acids Res. 34:462-471.

Ausubel, F. M., Brent, R., Kingston, R. E., Moore, D. D., Siedman, J. G., Smith, J. A., and Struhl, K. 2001. Current Protocols in Molecular Biology. John Wiley and Sons, New York.

Baliji, S., Black, M. C., French, R., Stenger, D. C., and Sunter, G. 2004. Spinach curly top virus: A new Curtovirus species from Southwest Texas displaying incongruent gene phylogenies that suggest a history of recombination among curtoviruses. Phytopathology 94:772-779.

Baulcombe, D. C. 1999. Fast forward genetics based on virus-induced gene silencing. Curr. Opin. Plant Biol. 2:109-113.

Bisaro, D. M. 1996. Geminivirus replication. Pages 833-854 in: DNA Replication in Eukaryotic Cells. M. DePamphilis, ed. Cold Spring Harbor Laboratory Press, Cold Spring Harbor, NY, U.S.A.

Carrington, J. C., Kasschau, K. D. \& Johansen, L. K. 2001. Activation and suppression of RNA silencing by plant viruses. Virology 281:1-5.

Frischmuth, S., T. Frischmuth, and Jeske, H. 1991. Transcript mapping of Abutilon mosaic virus, a geminivirus. Virology 185:596-604.

Frischmuth, S., Frischmuth, T., Latham, J. R., and Stanley, J. 1993. Transcriptional analysis of the virion-sense genes of the geminivirus Beet curly top virus. Virology 197:312-319.

Hanley-Bowdoin, L., Settlage, S., Orozco, B. M., Nagar, S., and Robertson, D. 1999. Geminiviruses: Models for plant DNA replication, transcription, and cell cycle regulation. Crit. Rev. Plant Sci. 18:71-106.

Hao, L., Wang, H., Sunter, G., and Bisaro, D. M. 2003. Geminivirus AL2 and L2 proteins interact with and inactivate SNF1 kinase. Plant Cell 15:1034-1048.

Hormuzdi, S. G., and Bisaro, D. M. 1995. Genetic analysis of Beet curly top virus: Examination of the roles of L2 and L3 genes in viral pathogenesis. Virology 206:1044-1054.

Lee, S., Stenger, D. C., Bisaro, D. M., and Davis, K. R. 1994. Identification of loci in Arabidopsis that confer resistance to geminivirus infection. Plant J. 6:525-535.

Martin, D. P., Willment, J. A., and Rybicki, E. P. 1999. Evaluation of Maize streak virus pathogenicity in differentially resistant Zea mays genotypes. Phytopathology 89:695-700.

Mullineaux, P. M., Rigden, J. E., Dry, I. B., Krake, L. R., and Rezaian, M. A. 1993. Mapping of the polycistronic RNAs of Tomato leaf curl virus. Virology 193:414-423.

Preiss, W., and Jeske, H. 2003. Multitasking in replication is common among geminiviruses, J. Virol. 77:2972-2980.

Rogers, S. G., Klee, H. J., Horsch, R. B., and Fraley, R. T. 1987. Improved 
vectors for plant transformation: Expression cassette vectors and new selectable markers. Methods Enzymol. 153:253-277.

Rybicki, E. P., Briddon, R. W., Brown, J. E., Fauquet, C. M., Maxwell, D. P., Harrison, B. D., Markham, P. G., and Stanley, J. 2000. Geminiviridae. Pages 285-297 in: Virus Taxonomy. Seventh Report of the International Committee on Taxonomy of Viruses. M. H. V. van Regenmortel, C. M. Fauquet, D. H. L. Bishop, E. B. Carstens, M. K. Estes, S. M. Lemon, J. Maniloff, M. A. Mayo, D. J. McGeoch, C. R. Pringle, and R. B. Wickner, eds. Academic Press, London.

Rybicki, E. P. 1998. A proposal for naming geminiviruses: A reply by the Geminiviridae Study Group Chair. Arch. Virol. 143:421-424.

Shivaprasad, P. V., Akbergenov, R., Trinks, D., Rajeswaran, R., Veluthambi, K., Hohn, T., and Pooggin, M. M. 2005. Promoters, transcripts, and regulatory proteins of Mungbean yellow mosaic geminivirus. J. Virol. 79:8149-8163.

Stanley, J., Markham, P. G., Callis, R. J., and Pinner, M. S. 1986. The nucleotide sequence of an infectious clone of the geminivirus Beet curly top virus. EMBO (Eur. Mol. Biol. Organ.) J. 5:1761-1767.

Stanley, J., Latham, J., Pinner, M. S., Bedford, I., and Markham, P. G. 1992. Mutational analysis of the monopartite geminivirus Beet curly top virus. Virology 191:396-405.

Stenger, D. C. 1994. Complete nucleotide sequence of the hypervirulent $\mathrm{CFH}$ strain of Beet curly top virus. Mol. Plant Microbe Interact. 7:154157

Stenger, D. C., Revington, G. N., Stevenson, M. C., and Bisaro, D. M. 1991. Replicational release of geminivirus genomes from tandemly repeated copies: Evidence for rolling circle replication of a plant viral DNA. Proc. Natl. Acad. Sci. U.S.A. 88:8029-8033.

Sunter, G., and Bisaro, D. M. 1989. Transcription map of the B genome component of Tomato golden mosaic virus and comparison with $\mathrm{A}$ component transcripts. Virology 173:647-655.

Sunter, G., and Bisaro, D. M. 1991. Transactivation in a geminivirus: AL2 gene product is needed for coat protein expression. Virology 180:416-419.
Sunter, G., and Bisaro, D. M. 1992. Transactivation of geminivirus AR1 and BR1 gene expression by the viral AL2 gene product occurs at the level of transcription. Plant Cell 4:1321-1331.

Sunter, G., and Bisaro, D. M. 1997. Regulation of a geminivirus coat protein promoter by AL2 protein (TrAP): Evidence for activation and derepression mechanisms. Virology 232:269-280.

Sunter, G., and Bisaro, D. M. 2003. Identification of a minimal sequence required for activation of the Tomato golden mosaic virus coat protein promoter in protoplasts. Virology 305:452-462.

Sunter, G., Gardiner, W. E., and Bisaro, D. M. 1989. Identification of Tomato golden mosaic virus-specific RNAs in infected plants. Virology 170:243-250.

Sunter, G., Stenger, D. C., and Bisaro, D. M. 1994. Heterologous complementation by geminivirus AL2 and AL3 genes. Virology 203:203210.

Sunter, G., Sunter, J. L., and Bisaro, D. M. 2001. Plants expressing Tomato golden mosaic virus AL2 or Beet curly top virus L2 transgenes show enhanced susceptibility to infection by DNA and RNA viruses. Virology 285:59-70.

Townsend, R., Stanley, J., Curson, S. J., and Short, M. N. 1985. Major polyadenylated transcripts of Cassava latent virus and location of the gene encoding coat protein. EMBO (Eur. Mol. Biol. Organ.) J. 4:33-37.

van Wezel, R., Dong, X., Liu, H., Tien, P., Stanley, J., and Hong, Y. 2002. Mutation of three cysteine residues in Tomato yellow leaf curl virusChina $\mathrm{C} 2$ protein causes dysfunction in pathogenesis and posttranscriptional gene-silencing suppression. Mol. Plant Microbe Interact. 15:203208.

Wang, H., Hao, L., Shung, C.-Y., Sunter, G., and Bisaro, D. M. 2003. Adenosine kinase is inactivated by geminivirus AL2 and L2 proteins. Plant Cell 15:3020-3032.

Wang, H., Buckley, K. J., Yang, X., Buchmann, R. C., and Bisaro, D. M. 2005. Adenosine kinase inhibition and suppression of RNA silencing by geminivirus AL2 and L2 proteins. J. Virol. 79:7410-7418. 